\title{
فلسفة حرية الإبداع فى فن التصوير البدارى
}

\author{
بحث مقدم من \\ أ.م.د/ محمد حسن محمد عبد المنعم كشك من \\ الأستاذ المساعد بقسم التصوير - شعبة التصوير الجدارى \\ كلية الفنون الجميلة - جامعة الإسكندرية
}

مقدمة البحث

الإبداع هو محاولة لتتظيم الو اقع المدرك حين تستثار قدر ات الفنان الإبداعية من خلال

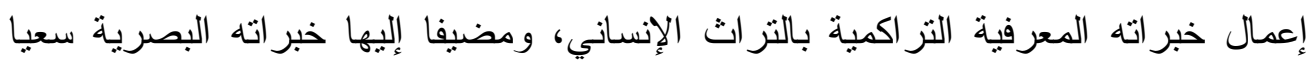

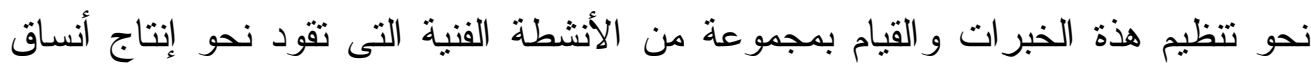
فنية جديدة .

الإبداع هو محاولة للتغلب على التحديات و المعوقات ومظاهر القصور فى عملية إنتاج العمل الفني ومعالجة التصورات الذهنية الفنية و التقنية ومحاولة استلهام تجارب التهات الآخرين

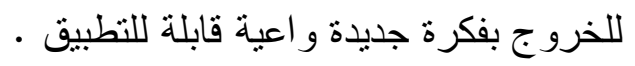
العملية الإبداعية لفن التصوير الجدارى تهدف إلى التى تقديم محتوى فنى يأتي من فهم

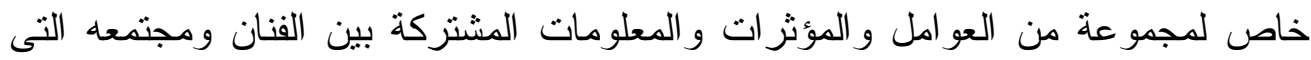

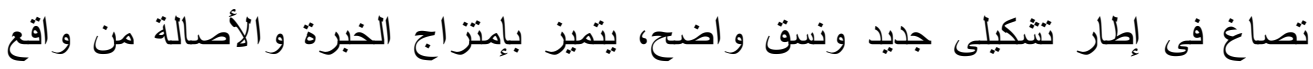

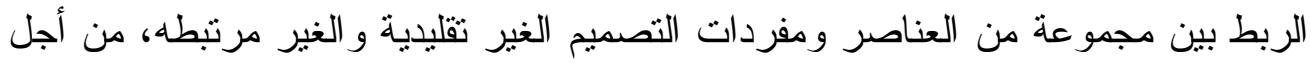

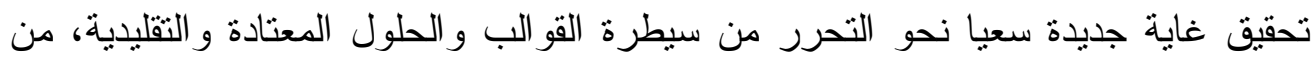

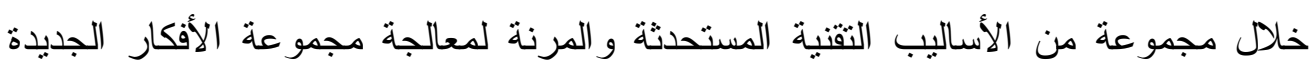
و التفسير الجيد للمعلومات التى تقود لعملية إدر الك ناجحة .

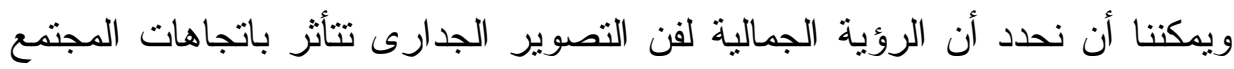

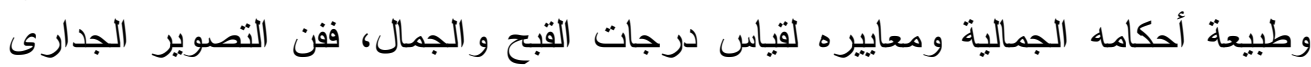

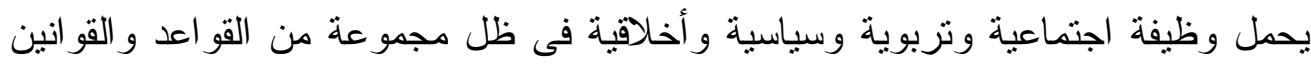

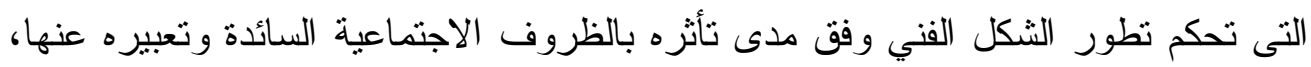

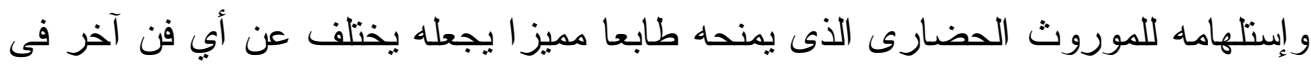

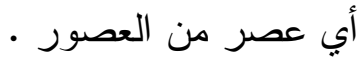


فنحن نجد فن التصوير الجدارى رغم إختلاف عصوره ومذاهبه ومدارسه وخامات

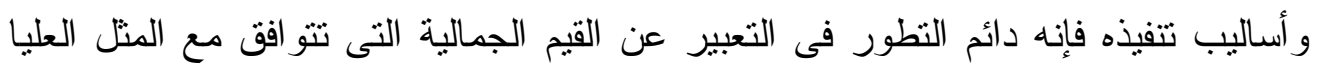

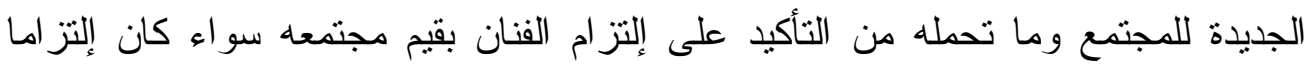

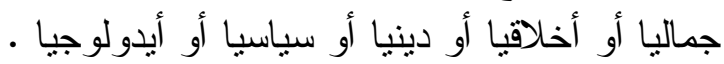

\section{مشكلة البحث}

العملية الإبداعية تحتوى علي عدة خطوات أو إجر اءات تفصيلية تتفاعل مع بعضها

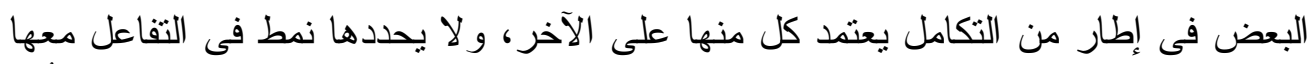

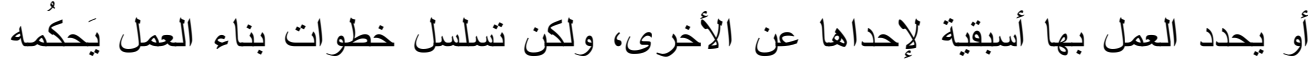

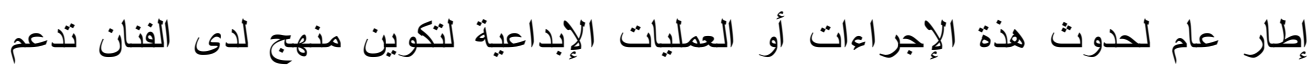

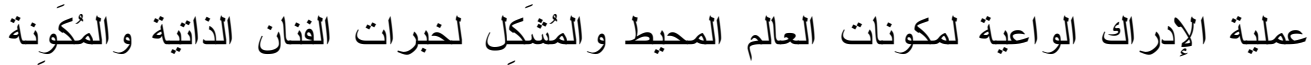

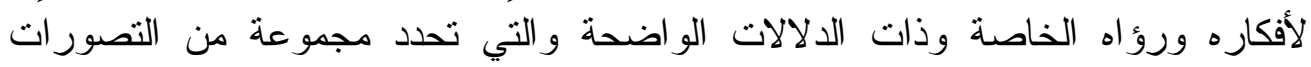

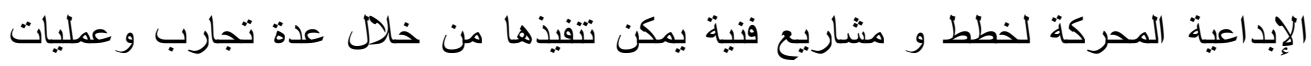

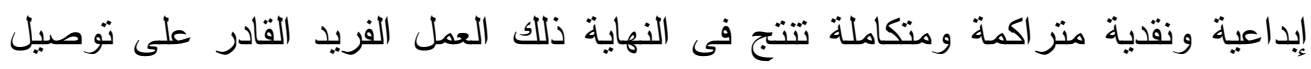

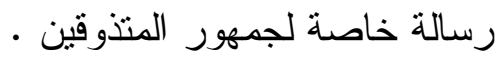
هدف البحث إبراز أهمية وضرورة التجربة الإبداعية للإنسان بإعتبار أن الفن بمفهومه العام و الفن

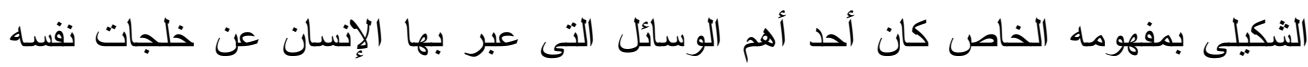

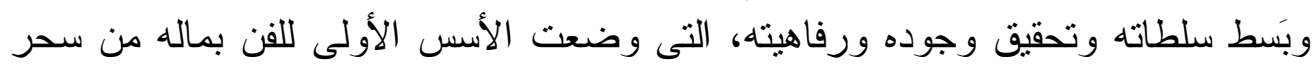

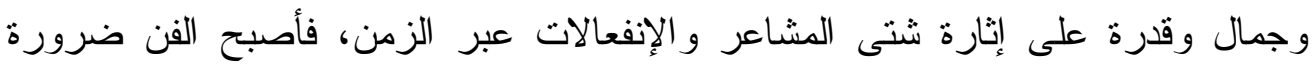

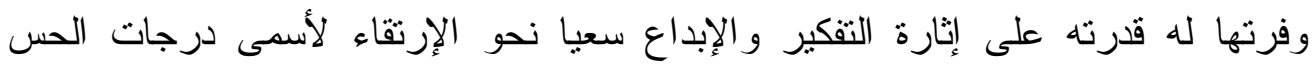

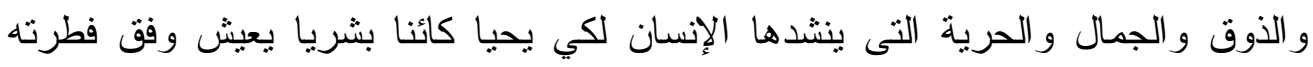

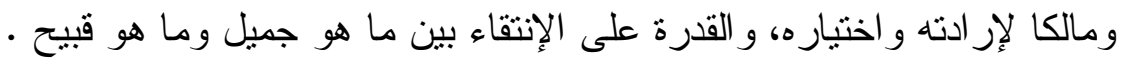

\section{مناهج البحث}

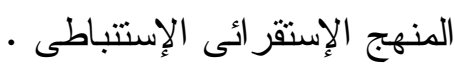
مصطلحات البحث الإنى الإن

[ العملية الإبداعية : هي سلسلة من الخطوات التي يقوم بها المبدع تبدأ بالثعور

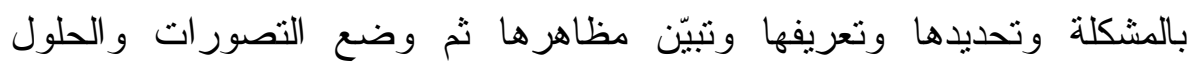

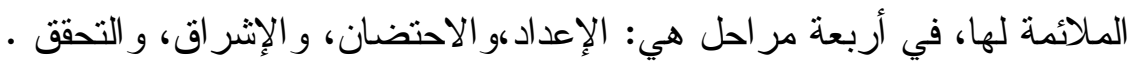

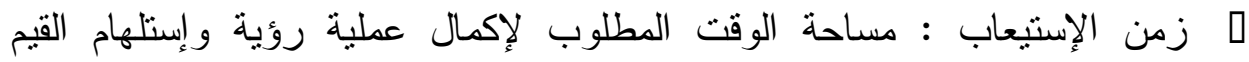

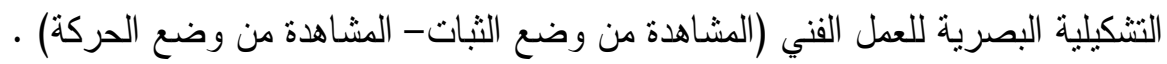




\section{Research Summary \\ An Introduction}

Creativity is an attempt to organize reality perceived disturbed while the creative capabilities of the artist through the realization of cumulative experience cognitive humanitarian heritage, and adding to the visual experience in an effort to organize these experiences and do a variety of artistic activities which lead to the production of new artistic formats.

Creativity is an attempt to overcome the challenges and obstacles and inefficiencies in the process of artistic production work and address the perceptions of mental and artistic and technical experiences of others inspired to try out a new idea of conscious applicable

The creative process, the art of mural painting aims to provide technical content comes from a special understanding of a range of factors and influences shared information and between the artist and society, which are formulated in the framework of a new Fine and clear format, featuring Bametzaj experience and originality of the reality of the link between a set of elements and vocabulary design of nonconventional and unrelated, in order to achieve a new highly in pursuit of freedom from the control of the templates and the usual solutions and traditional, through a combination of techniques developed and flexible to deal with the new set of ideas and good interpretation of the information that leads to the process of realization successful.

We can arrange that the aesthetic vision of the art of mural painting influenced by directions by society and the nature of aesthetic judgments and criteria for measuring the degree of ugliness and beauty, art of mural painting bears a social function and educational, political and ethical under a set of rules and Laws that develops form of technical control in accordance with the extent influenced by the prevailing social conditions and he put it, and inspired by the legacy of civilization, which gives him a distinctive character makes it different from any other art in any era of the ages.

We find the art of mural painting despite the different days through and doctrines and schools and ores and implementation methods it lasting development in the expression of aesthetic values that are compatible with the new ideals of the community and what was done to emphasize the commitment of the artist community values, whether committed aesthetically or morally or religiously or political or ideological.

\section{Research problem}

The creative process has several steps or detailed procedures to interact with each other in the framework of the integration of each depends on the other, and not determined by the pattern in the interaction with them or working out sets precedence for one another, 
but the sequence of steps building work is governed by a general framework because of this Allajraat or creative processes to form approach to the artist to support the process of cognition conscious of the components of the surrounding world and the problem of the experience of self-artist and made up for his ideas and visions own and with clear indications which outlines a range of creative concepts driving plans and artistic projects can be implemented through several experiments and innovative operations and cash accumulated and integrated in the end, produce unique work that is capable to deliver a private message to an audience of connoisseurs.

\section{Research Aim}

Highlight the importance and necessity of creative experience for a person considering that art general sense and Shukaily art special sense he was one of the most important means through the man from the longing itself and the extension of powers and the achievement of its existence and well-being, which laid the first foundations of art with his wealth of charm and beauty and ability to provoke various feelings and emotions through time, bringing art should be provided to him by his ability to provoke thinking and creativity in pursuit of upgrading to a higher degree of sense and taste and beauty and freedom sought by man in order to live a human being to live according to his nature and the owner of his will and choice, and the ability to The selection between what is beautiful and what is ugly.

\section{Research Methods}

Inductive deductive approach.

\section{Definitions of Research}

- The creative process: is a series of steps undertaken by the creative start to feel the problem and identified and defined and showing manifestations then put her perceptions of appropriate solutions, in four phases (preparation, incubation, and radiance, and verification).

- Absorption time: space of time required to complete the process of vision and inspiration Fine values for visual artwork. (Viewing position of stability - viewing of traffic mode)

\section{Mohammed Hassan Mohamed Abd Elmonem Keshk}




\section{مقدمة}

وُجدَ الإنسان لإعمار الأرض ومحاولا إحداث أكبر قدر من التو افق مع عناصر

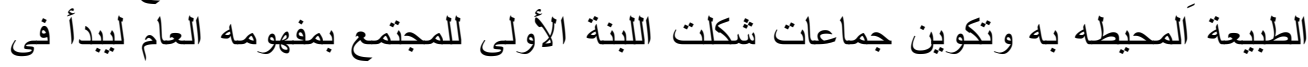

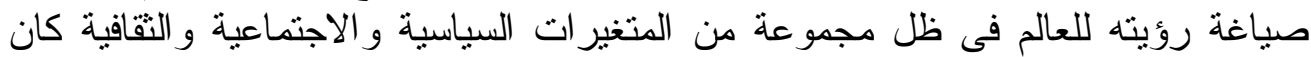

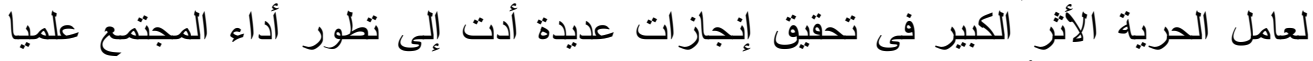

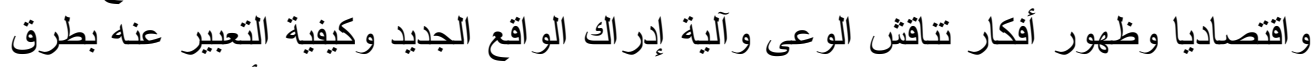

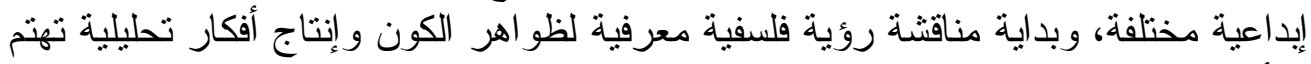

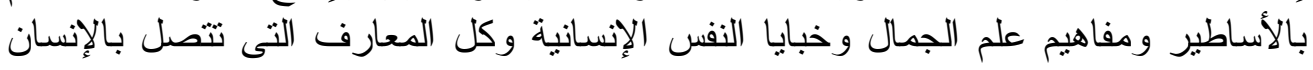
وطرق إدر اكه وتفرد شخصيته عاله وحريته

ارتبط الإبداع الفني بالتعبير عن قضايا المجتمع وتتكيل وتئه وعيه، (وقد عبر كارل

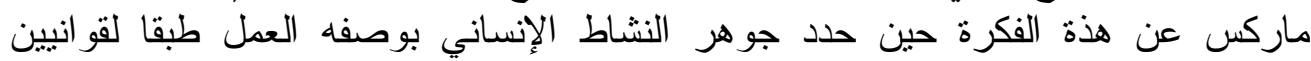

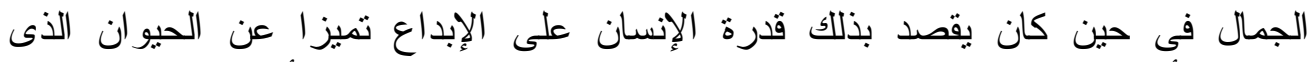

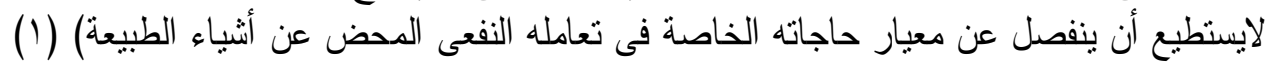

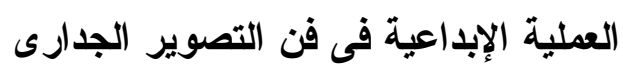

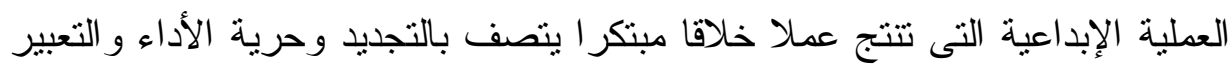

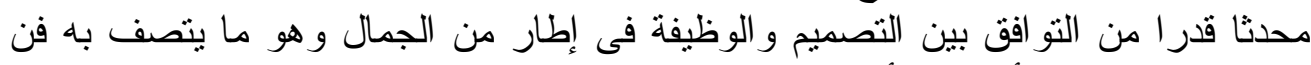

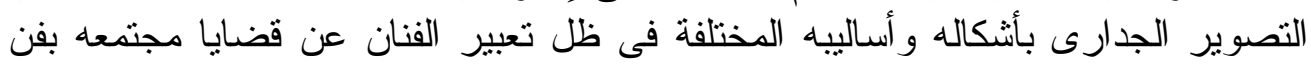

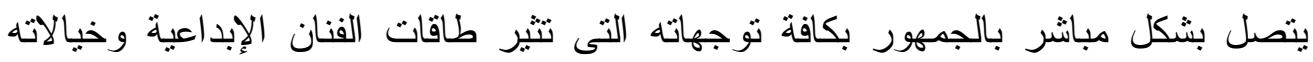

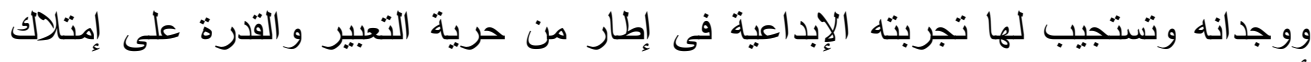

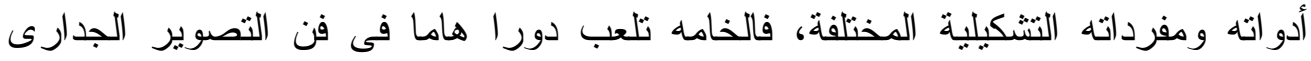

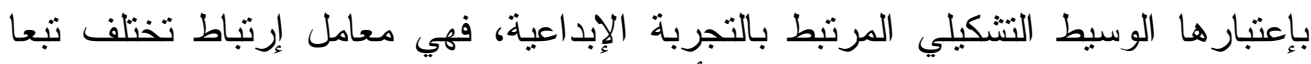

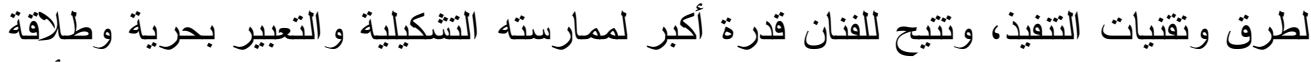

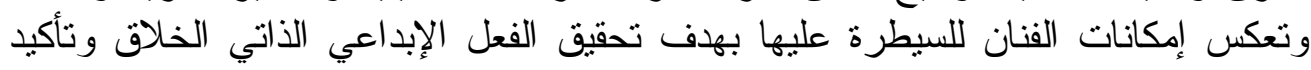

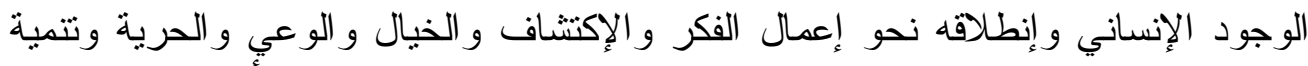

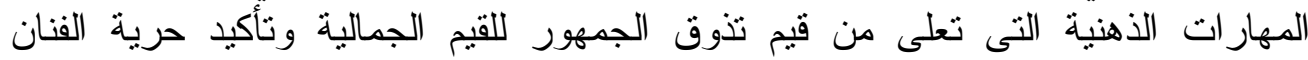

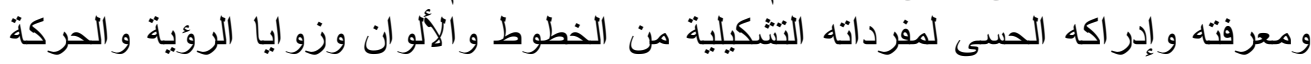

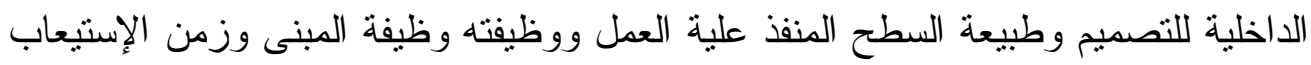

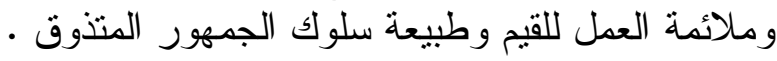

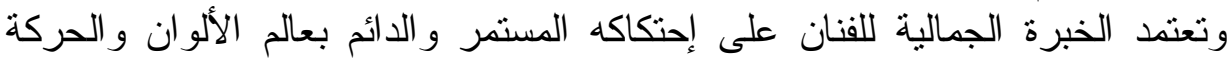

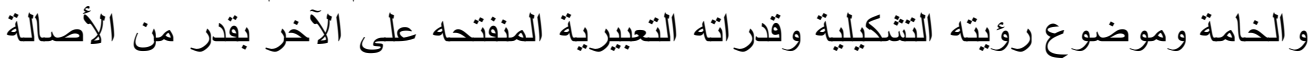

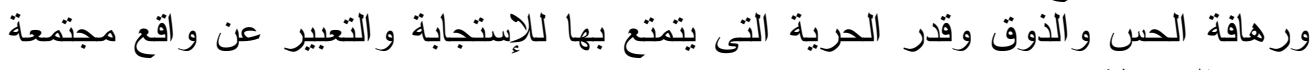
وبيئته المحيطة .

تختلف المدارس و الإتجاهات الفنية فى طرق صياغة العملية الإبداعية تبعا لتوجهاتها

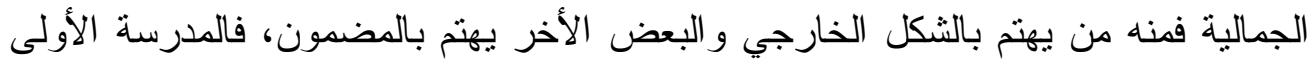

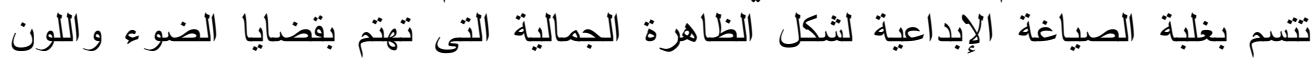


وتقنيات التتفيذ وتحليل المشهر بشكل هندسى منل أعمال العمارة، والمدرسة الثانية تهتم

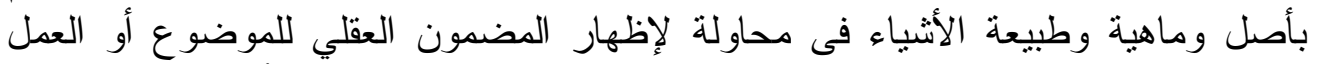

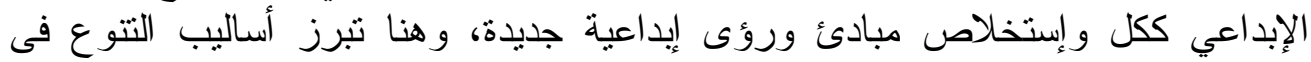

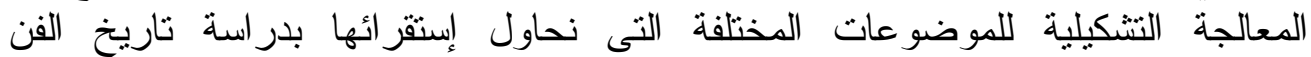
ونستخلص من خلال تجربة الفنان فى الإبداعية و عملية الإبتكار وتصنيف العهات العمل الفني

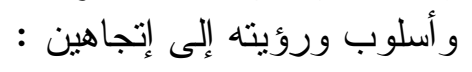

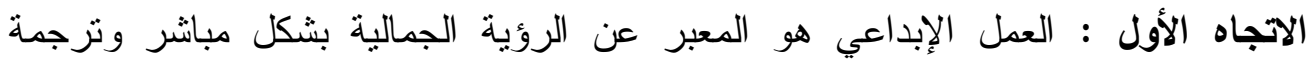

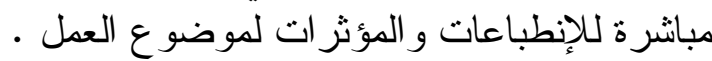

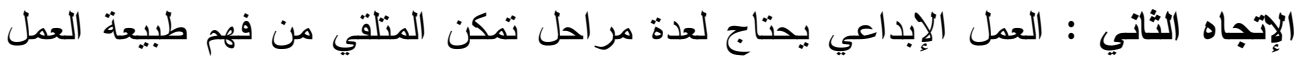

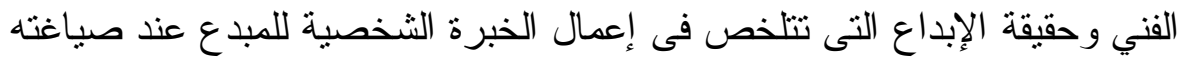

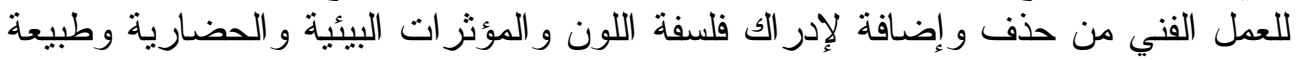

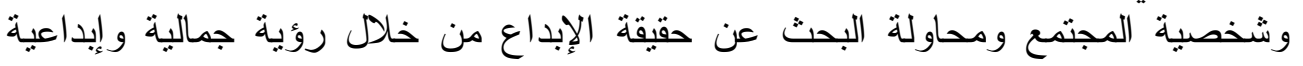

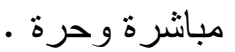

وقد يؤثر الإطار المجتمعي على المبدع فيجعله متأرجحا بين تقيبد إنفعالاته ونز عتها

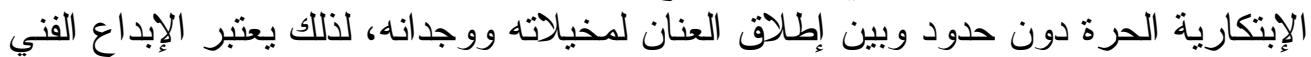

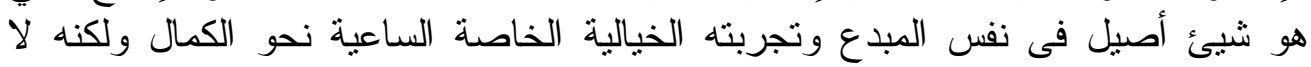

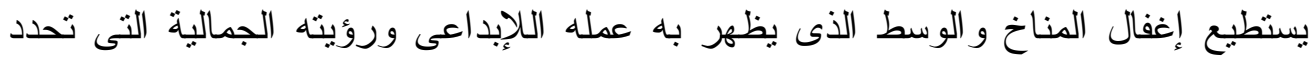

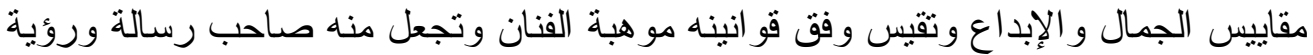

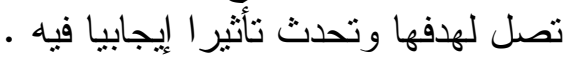

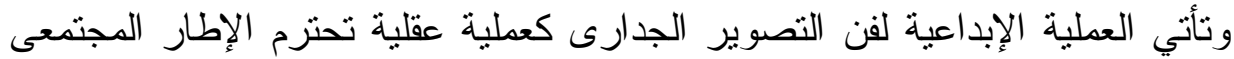

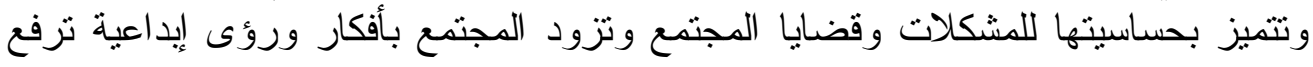

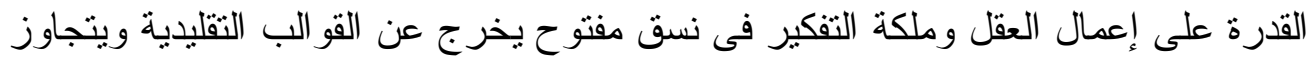

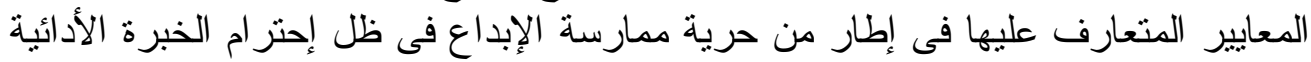

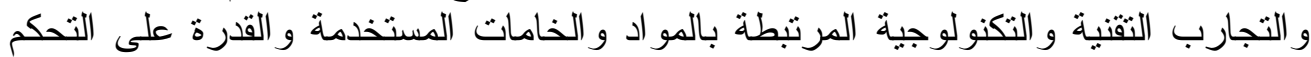

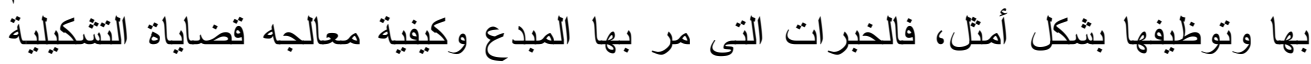

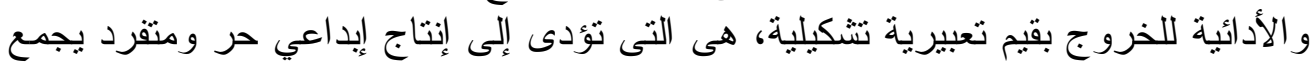

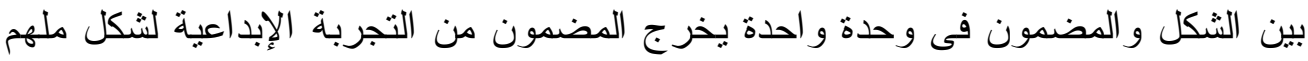

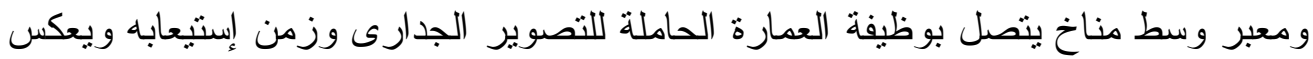

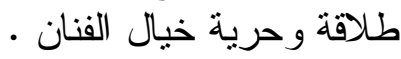

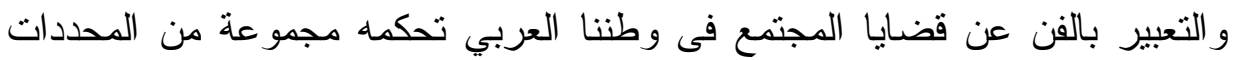

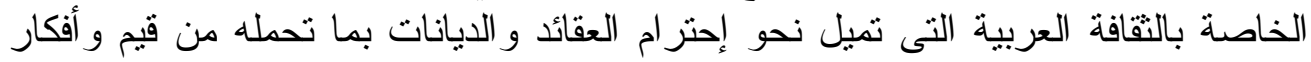

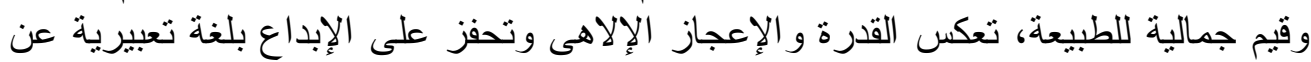

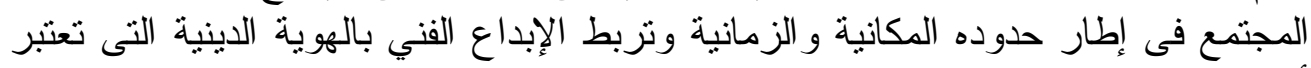

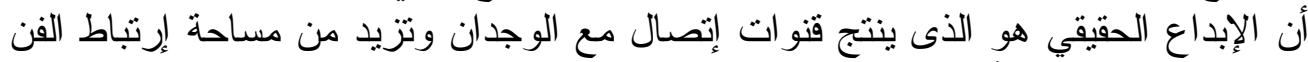

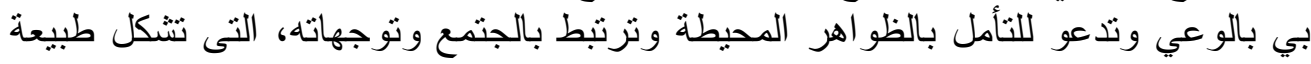


الحالة الإبداعية التى تحمل قيم الحق والخير و الجمال و الزمان و المكان الواجب تو الفرها

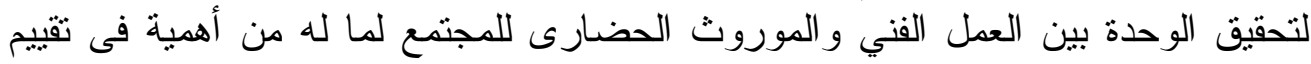

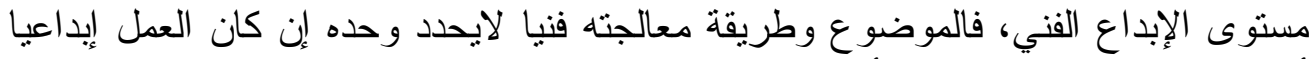

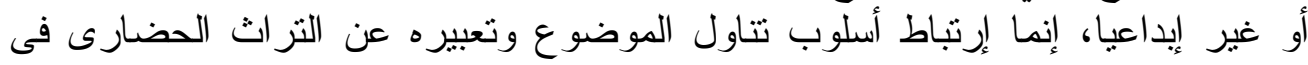

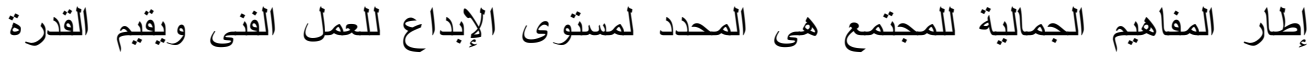

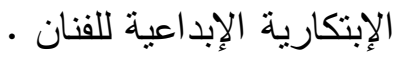

\section{مفهوم العملية الإبداعية}

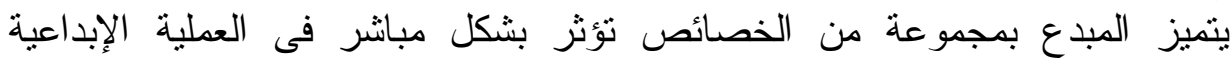

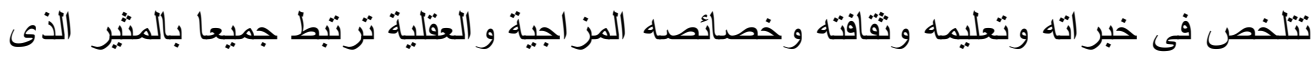

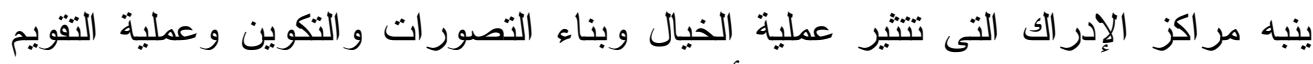

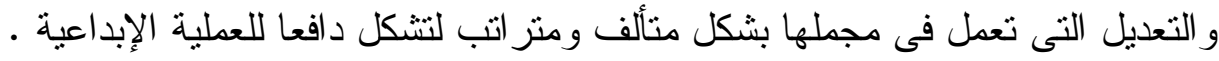

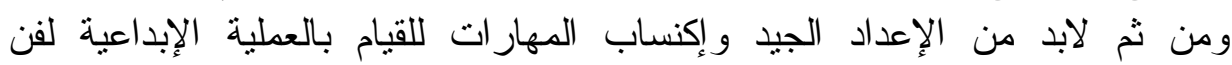

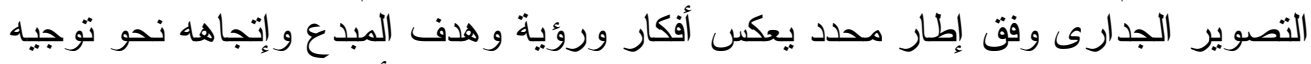

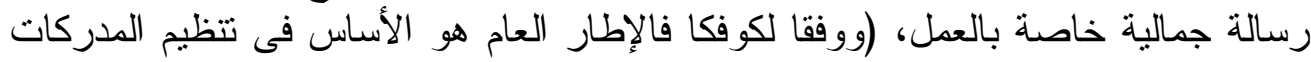

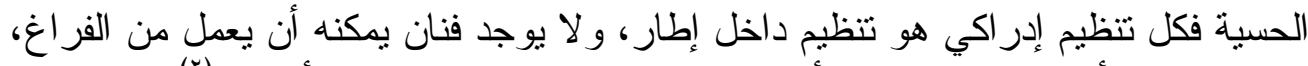

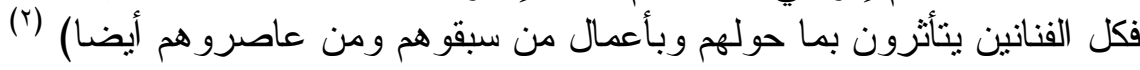

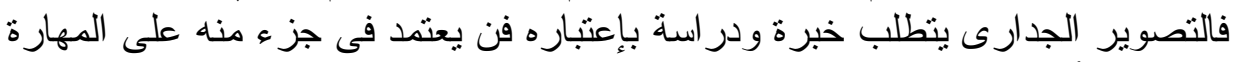

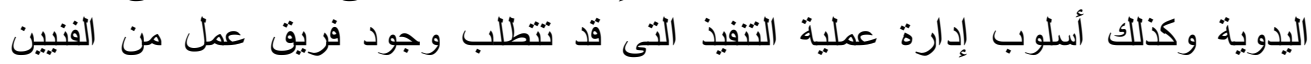

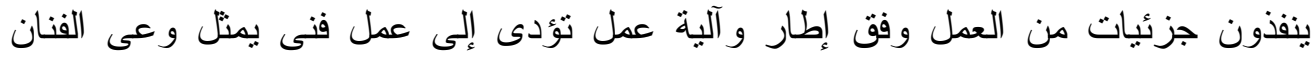

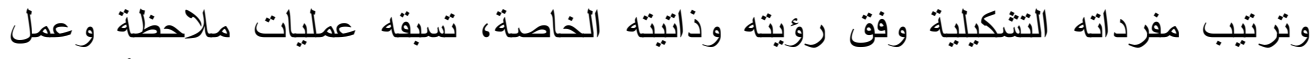

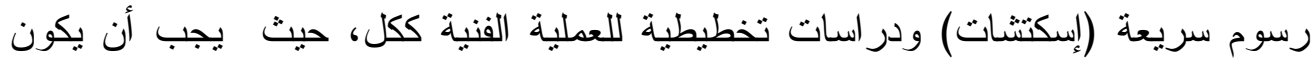

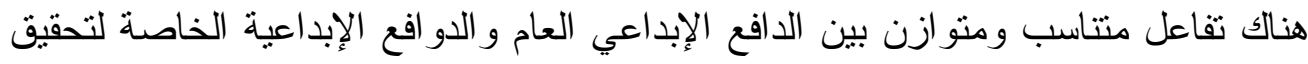

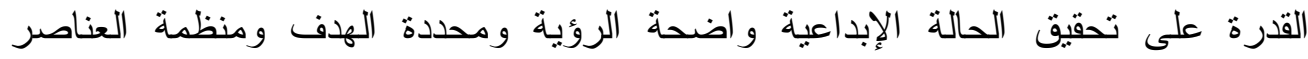

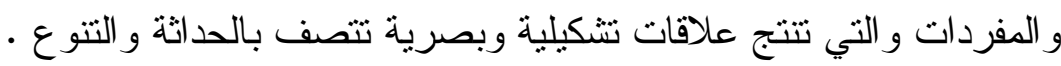

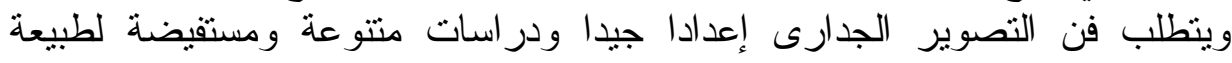

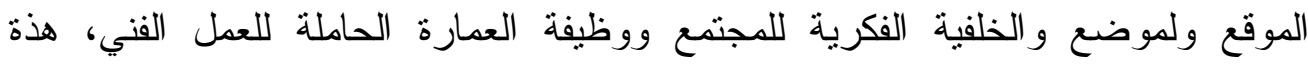

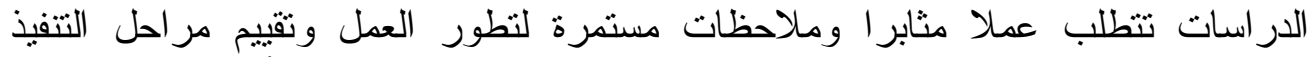

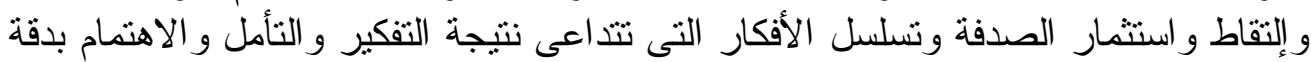

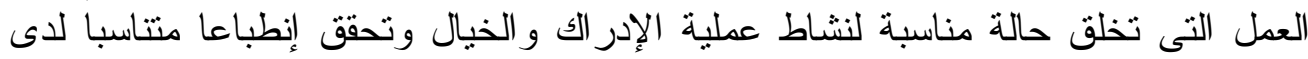

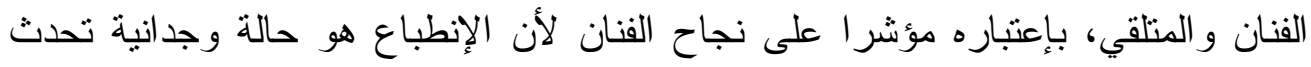

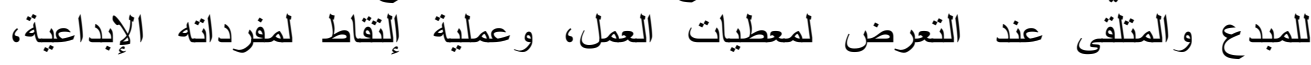

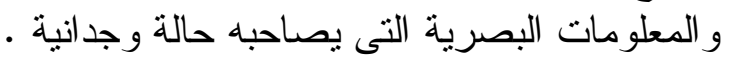

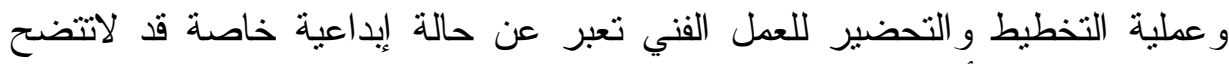

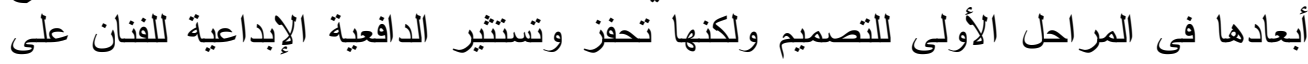

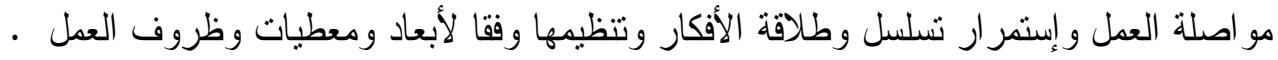


ويمنل الخيال أحد محاور طلاقة العملية الإبداعية ووسيلة لتنظيم الأفكار وصياغتها

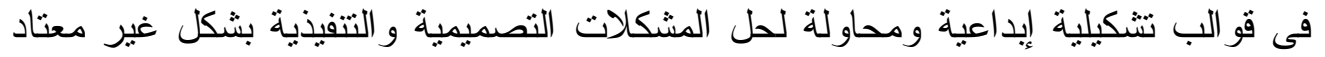

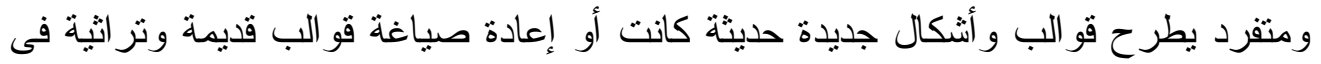

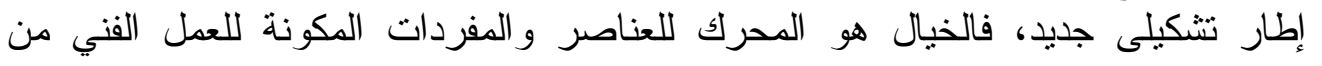

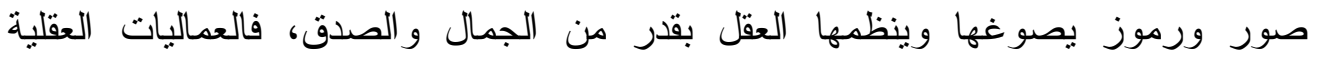

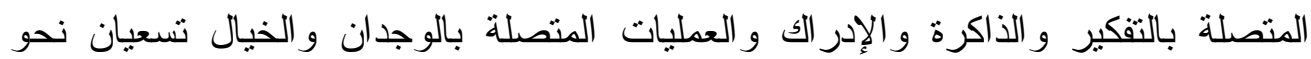

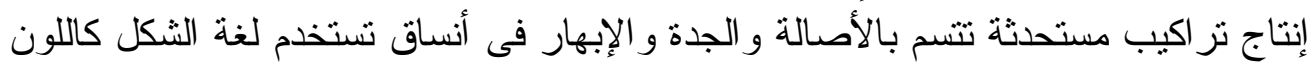

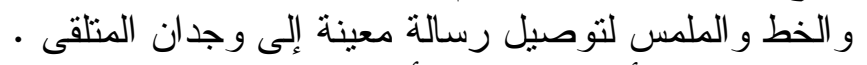

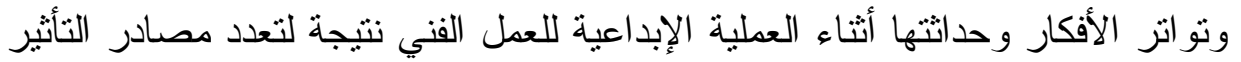

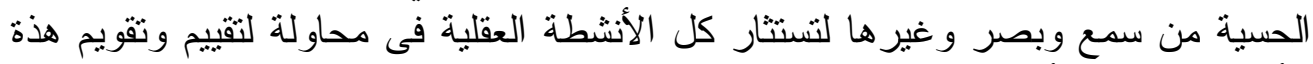

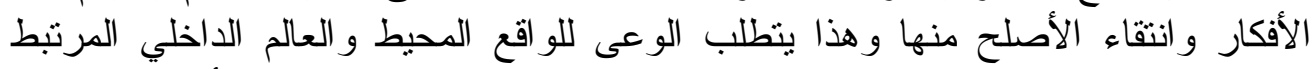

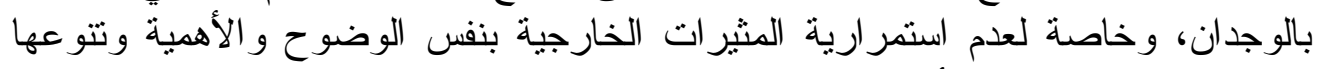

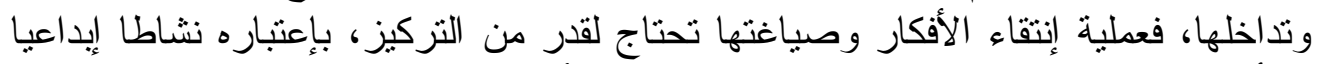

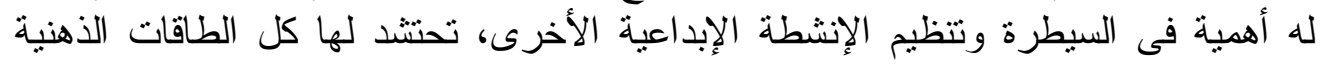

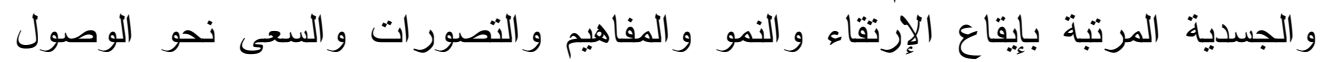

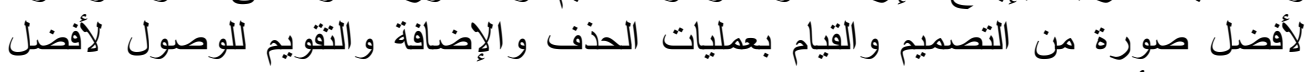

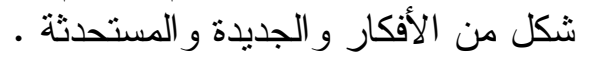

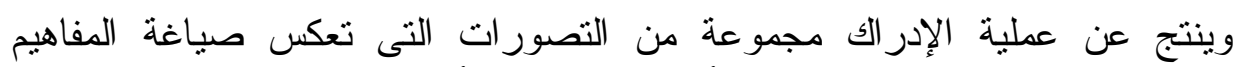

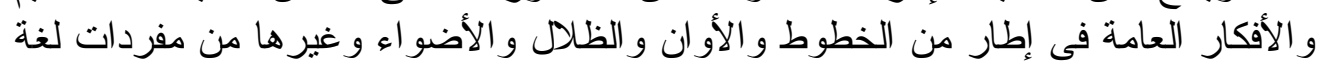

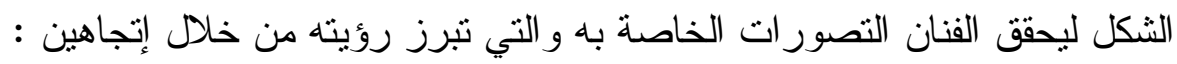

الإتجاة الأول : الإنجان

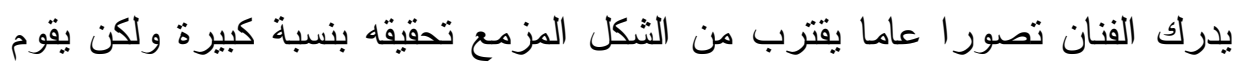

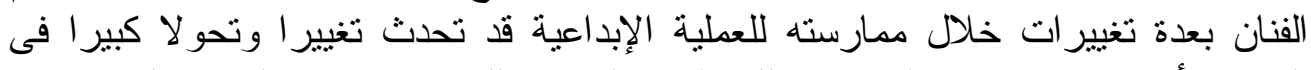

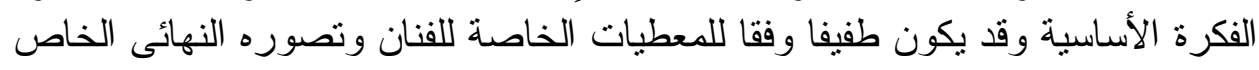
الإتجاه الثاني :

يتبلور تصور الفنان تبعا لانفعاله وتأثير ذلك على تسلسل أفكاره خلال ممارسته

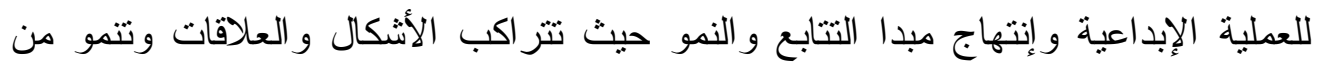

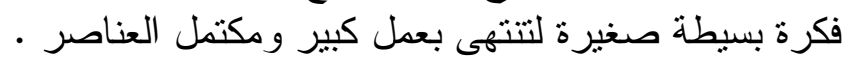

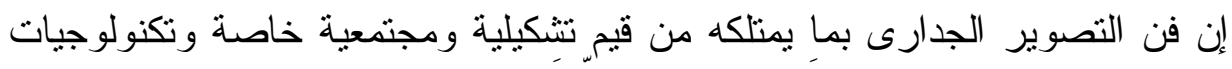

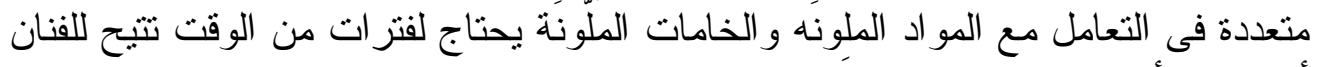

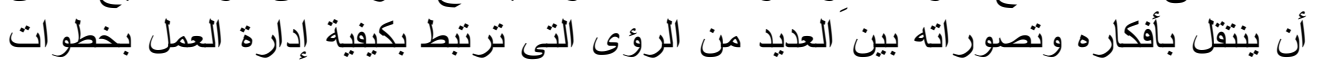

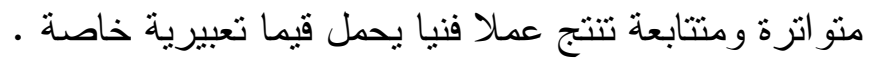




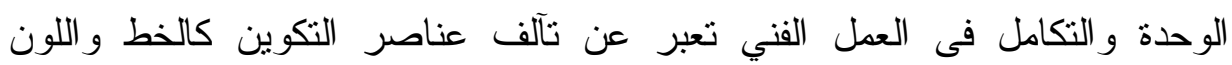

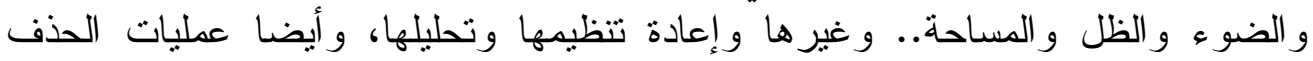

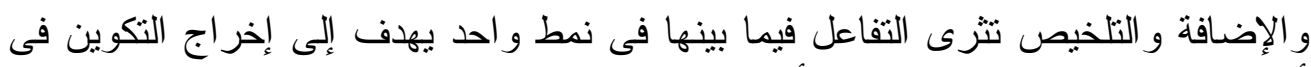

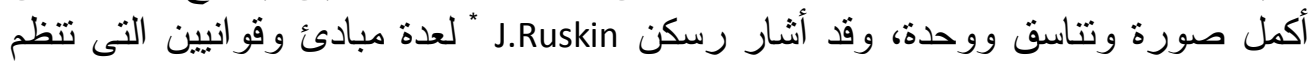
التكوين كما يلي : الأوني :

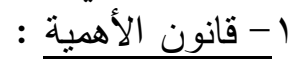
يقوم على العنصر الرئيسي الذئى يحدده الفنان كحور للتكوين وملامحه لها أهمية خاصة

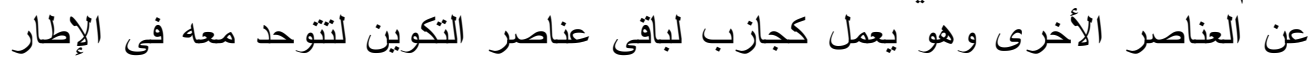

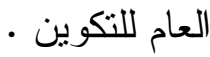

$$
\text { ب- قانون التكر ارن }
$$

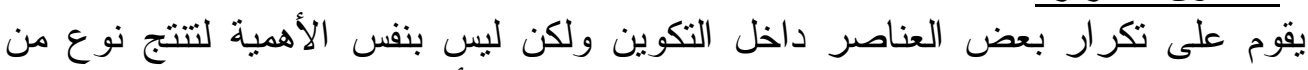

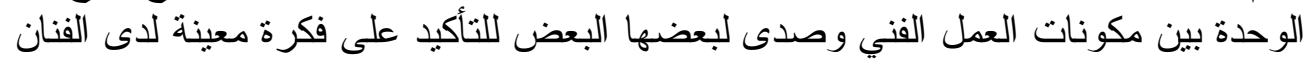

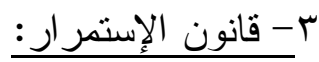

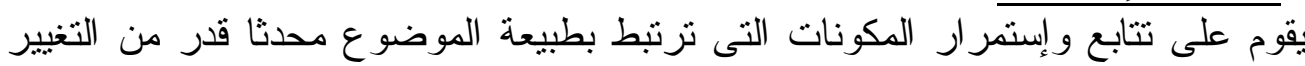

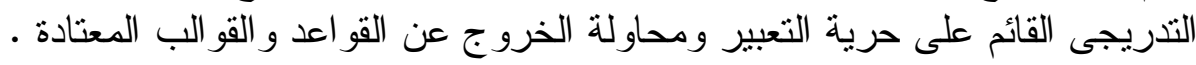

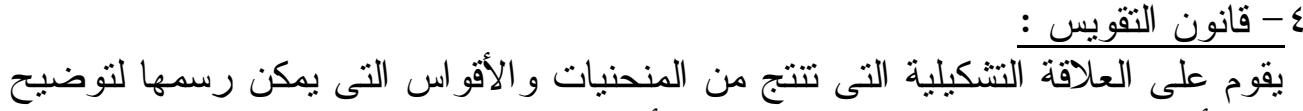

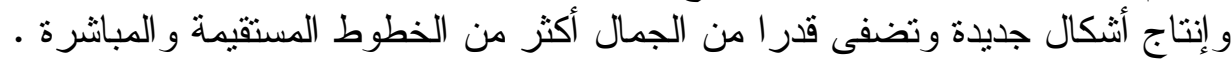
يقوم عانون التضاد :

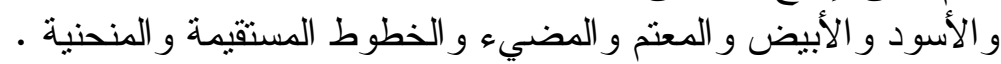

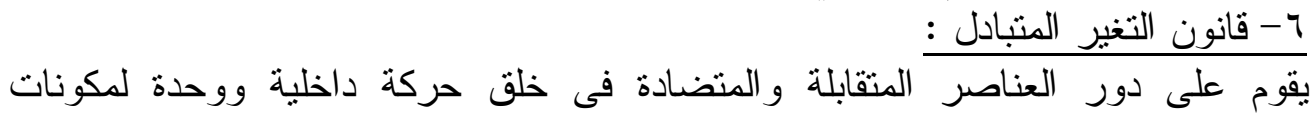
التصميم لأن التغير الحادث لعنصر ما يترتبط بتغير مماتل للعنصر الأخر ولكن ليس ولئ بنفس لئس

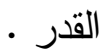
يقوم على إنتظام عناصر الإتساق : • الفني

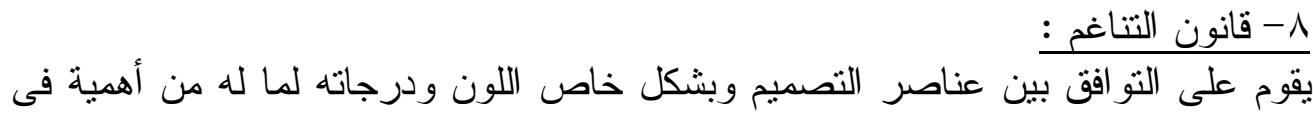

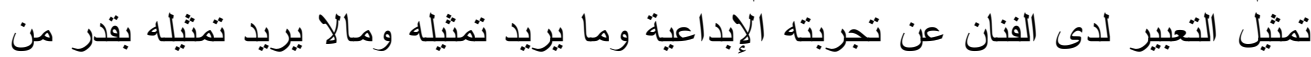

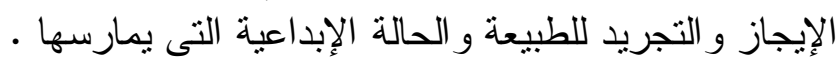


يقوم قانون الإثعاع :

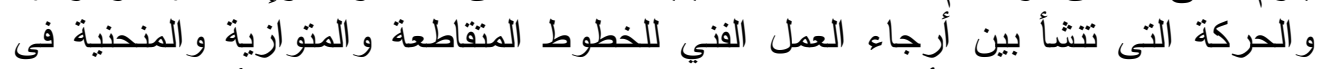

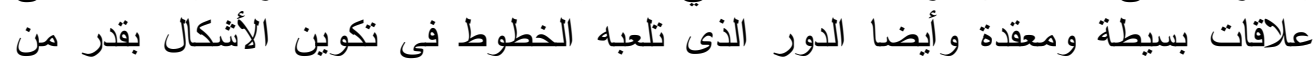

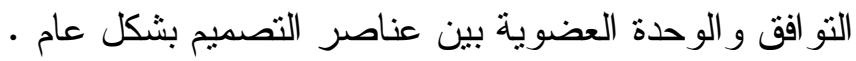

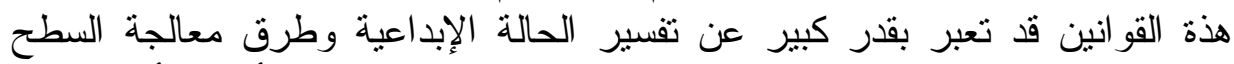
تشكيليا وعبر عن المنهج العام للعمل الفني وصياغته، ولكن ولكن الإتجاه نحو أعمالا أكثر تعقيدال

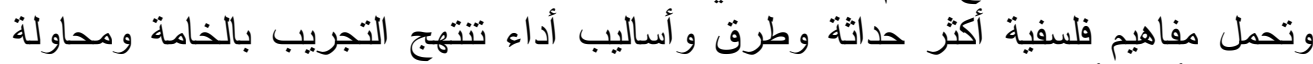

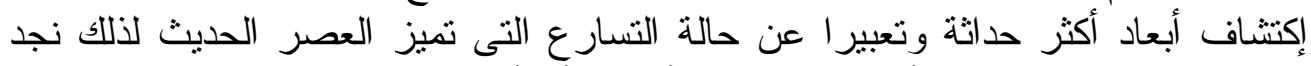

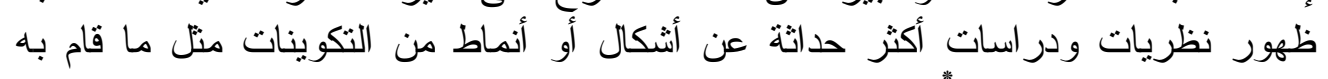

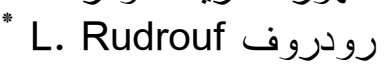

تقوم على تجانس توزيع الإنتارية :

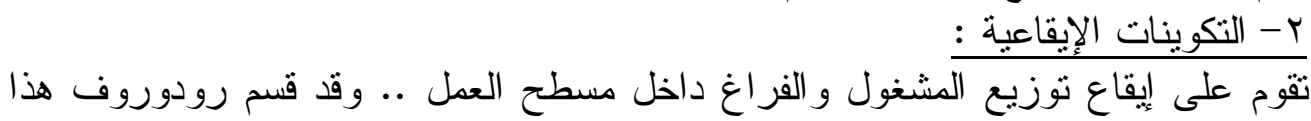

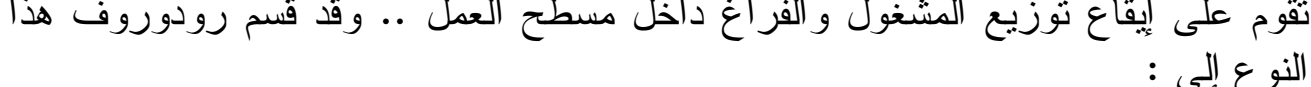
تتزتب عناصر التصميم حول محور رئيسي يشكل مركز اللتكوين أو عدة أثنكال تقوم على

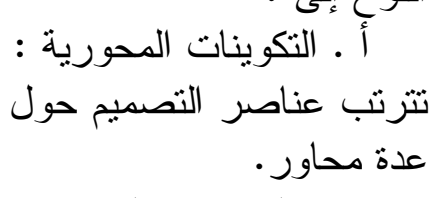

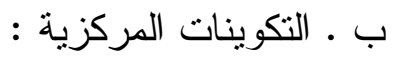
تتطلق عناصر التصميم من نقطة مركزية بالتكوين :

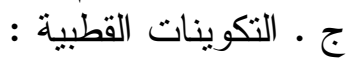
تقوم على العلاقة الديناميكية بين مجمو عتين منقابلتين من الأثكال .

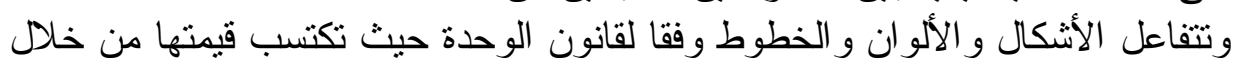

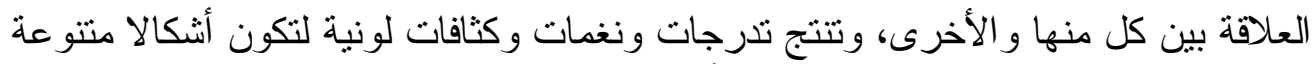

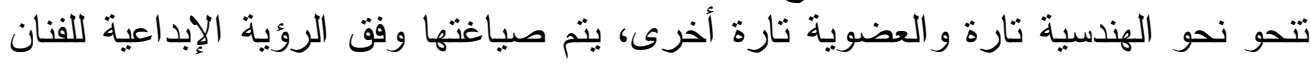

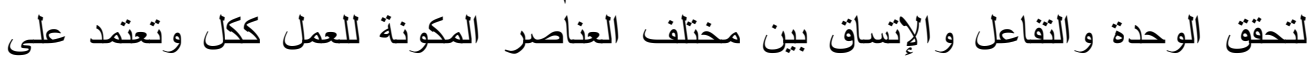

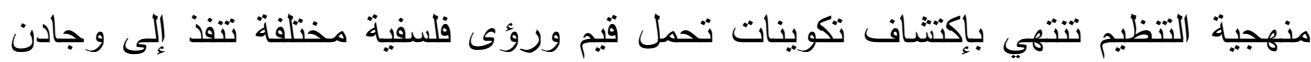

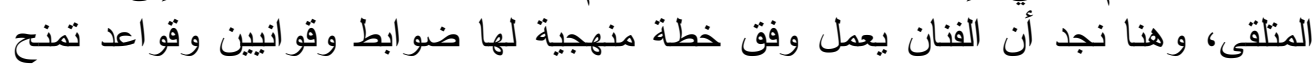

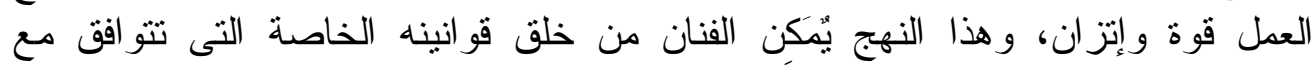

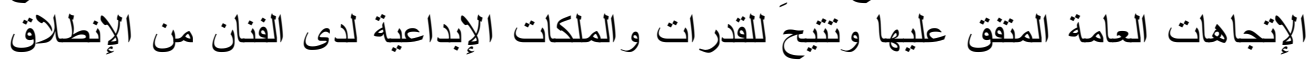

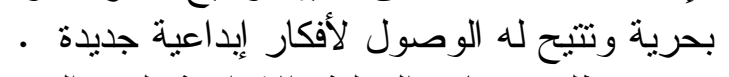

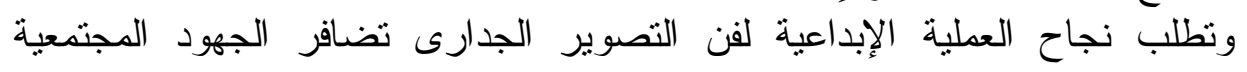

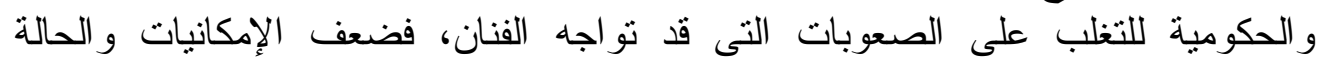
الاقتصادية و النسق الإجتماعى قد تؤدى إلى نقص فى الرؤية وندرة فى المعلومات وبات وبالتالي 


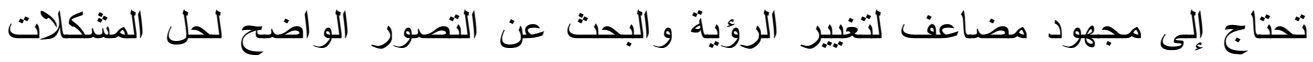

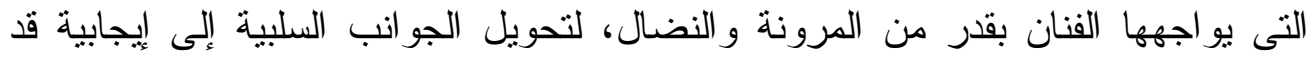

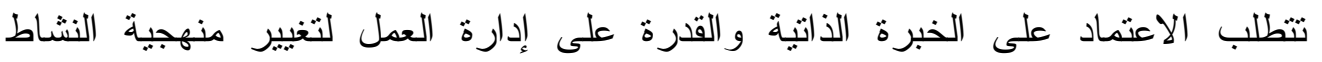

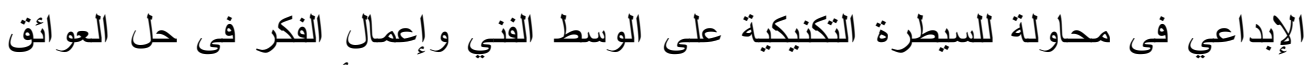

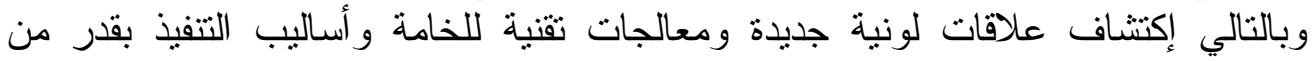

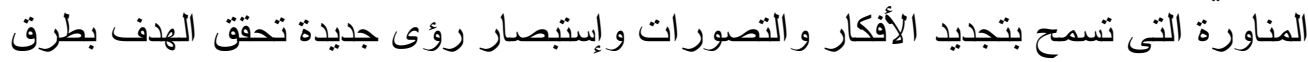

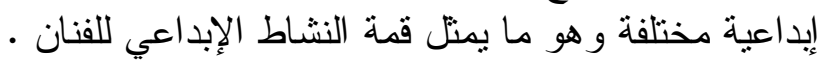

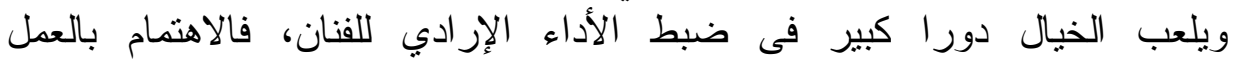

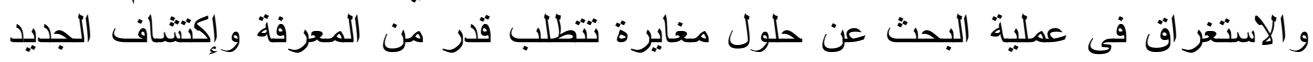

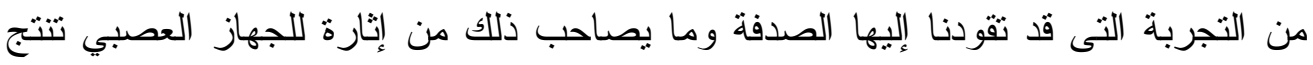

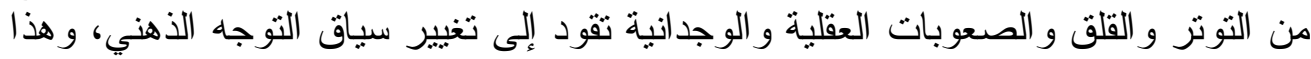

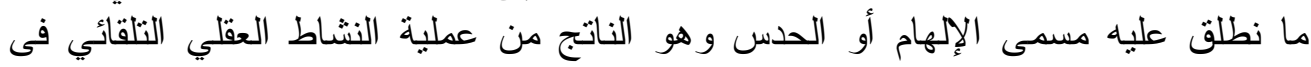

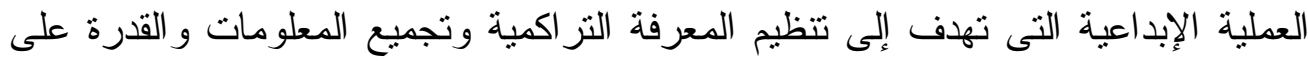

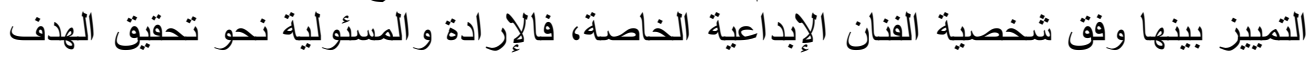

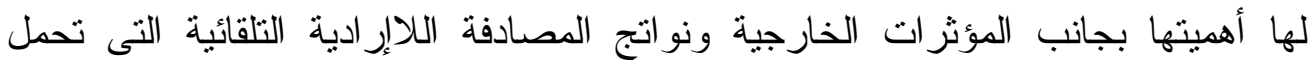

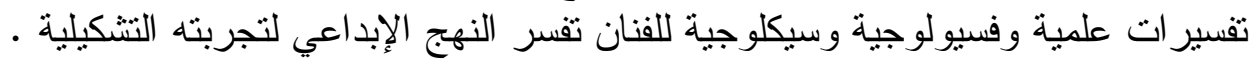

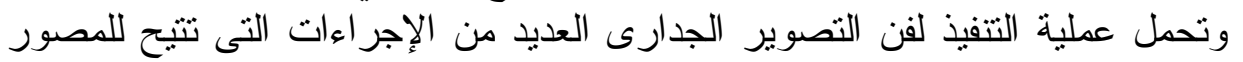

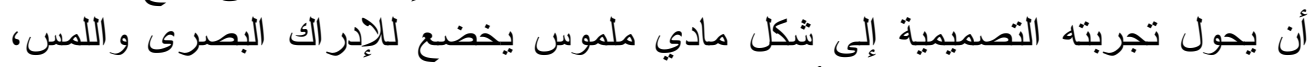

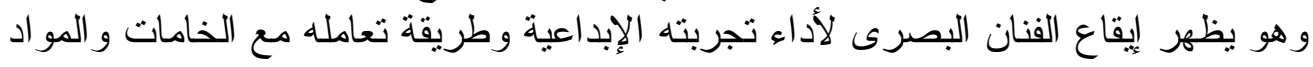

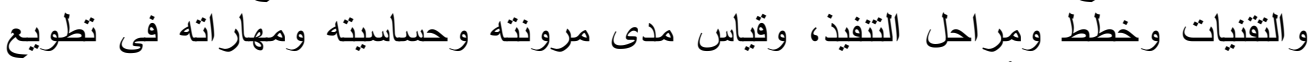

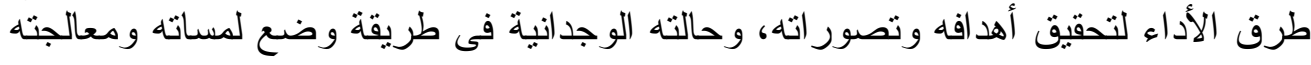

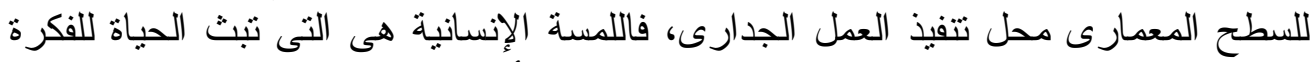

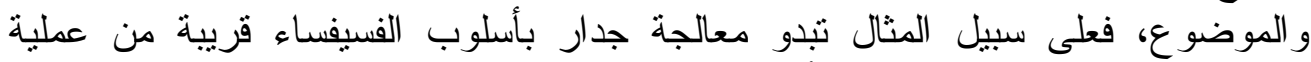

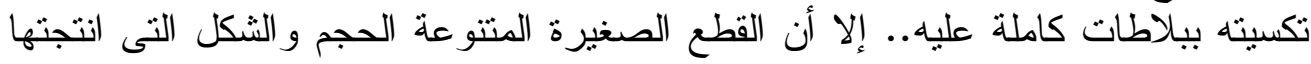

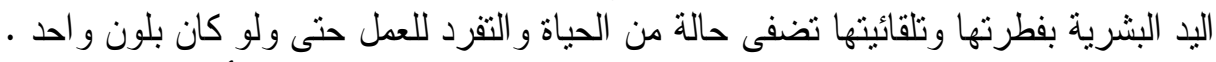

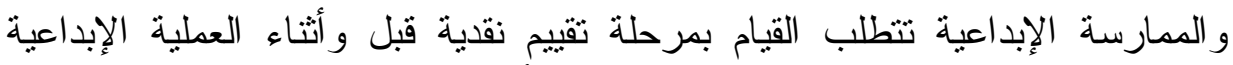

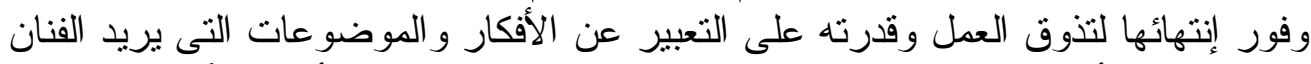

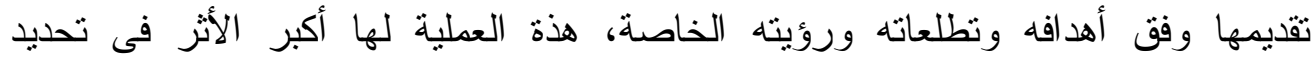

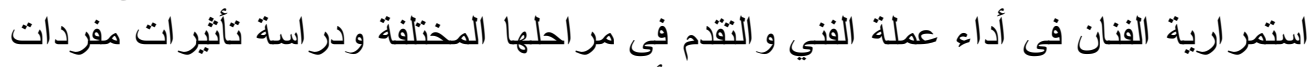

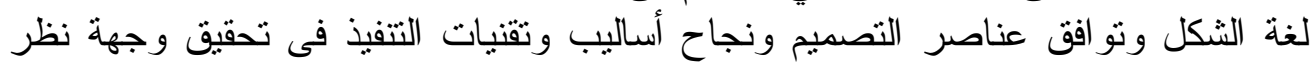

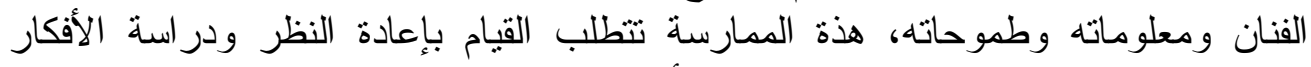

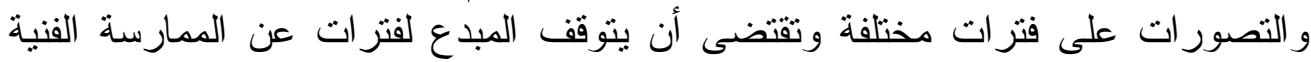

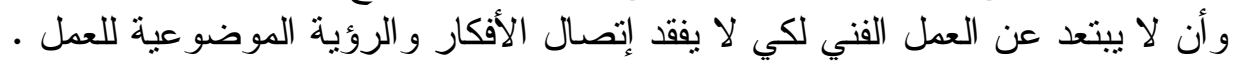

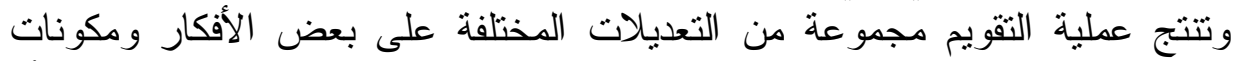

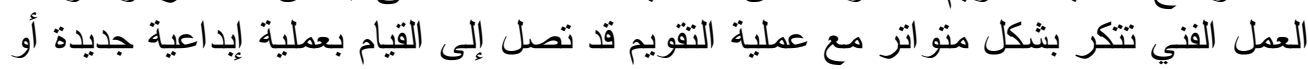


موازية للعملية الأصلية وبالتالي تغير من الصياغة ووجهة النظر حتى يصل المبدع لحالة

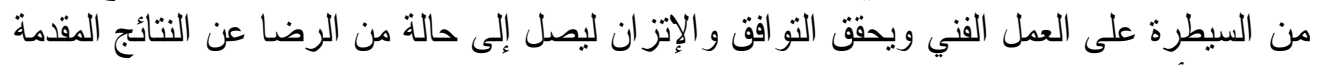

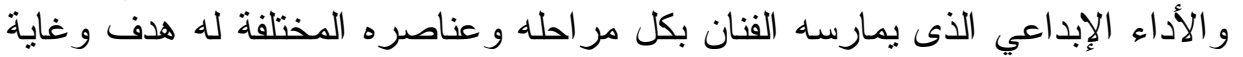

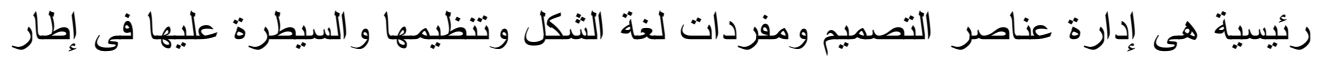

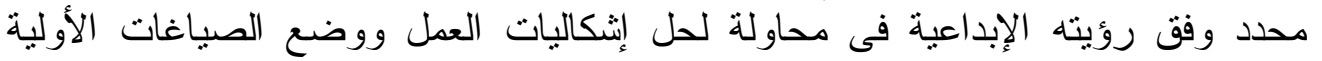

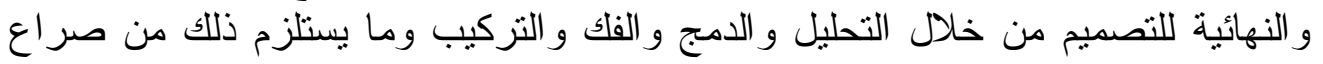

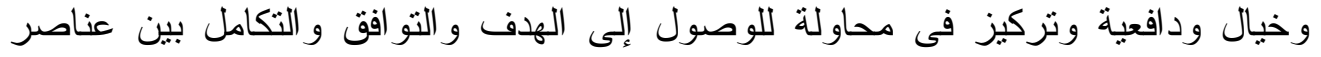

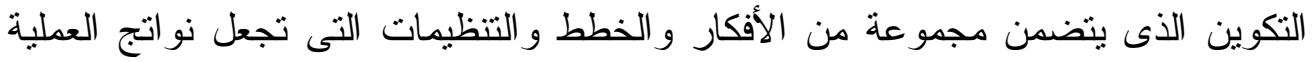

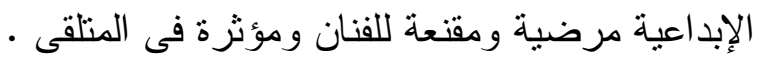

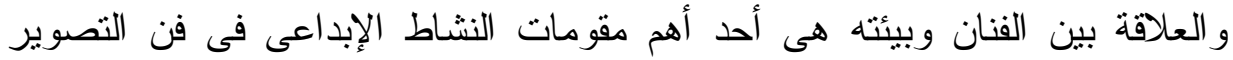

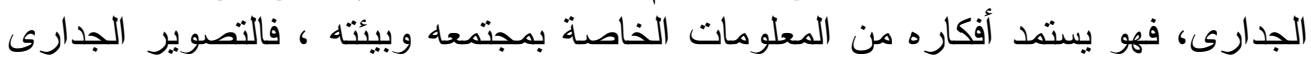

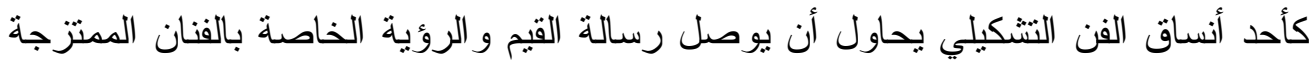

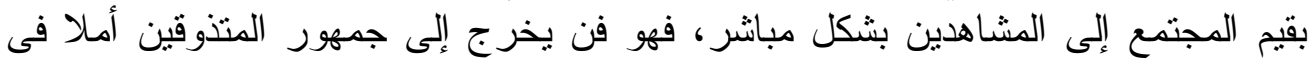

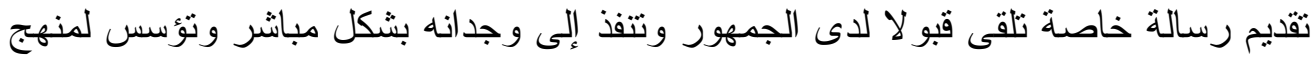

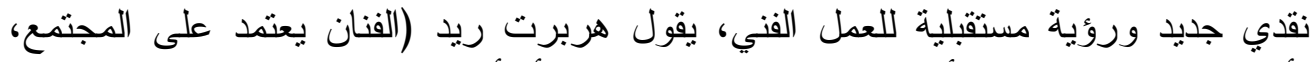

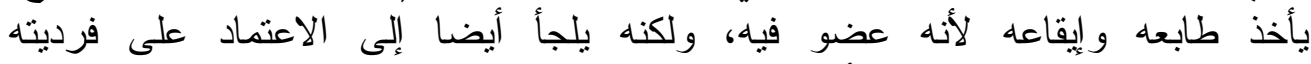

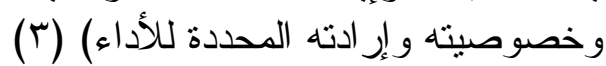

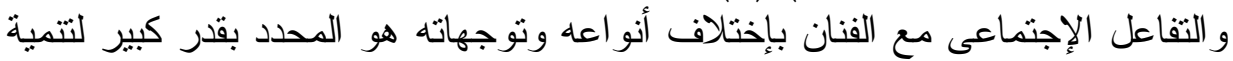

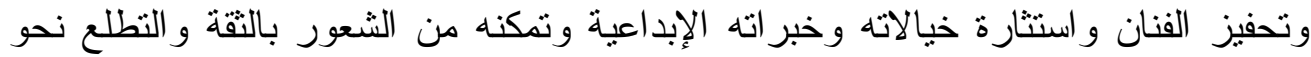

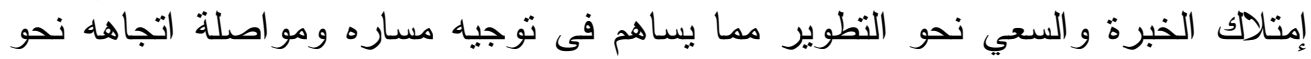

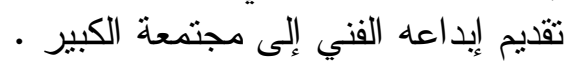

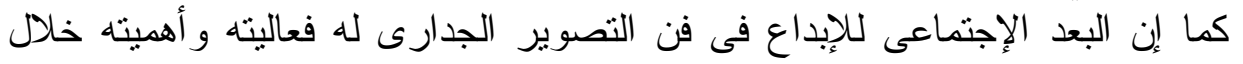

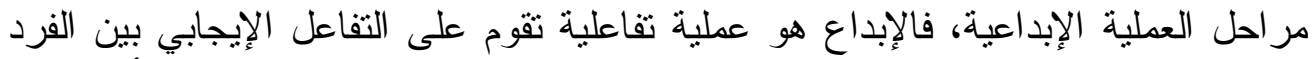

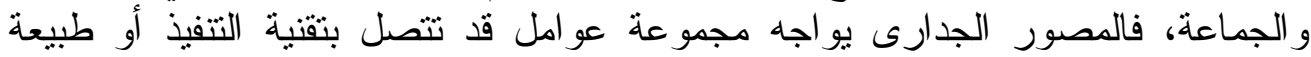

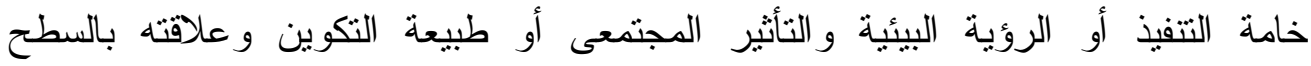

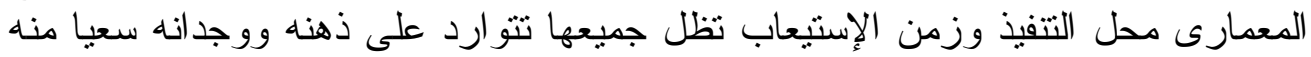

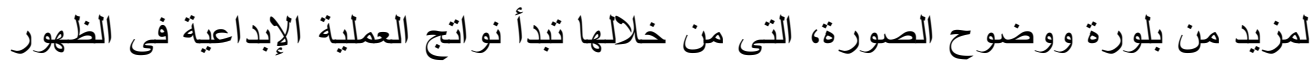

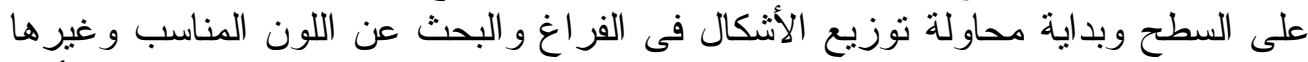

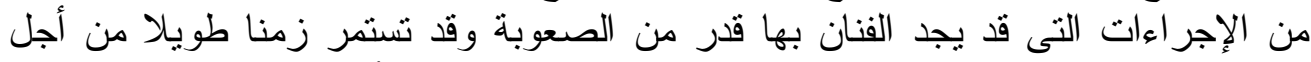

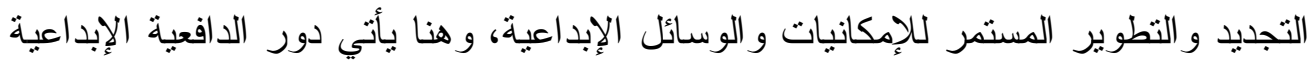

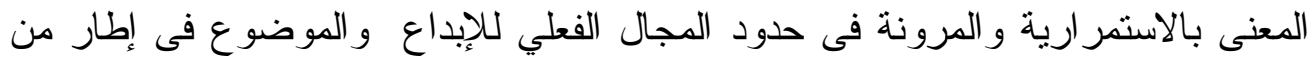

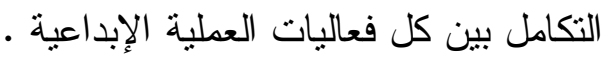

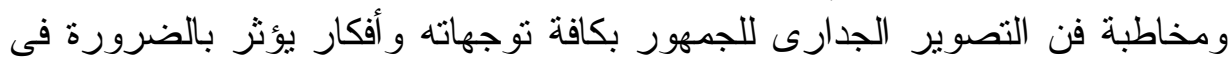

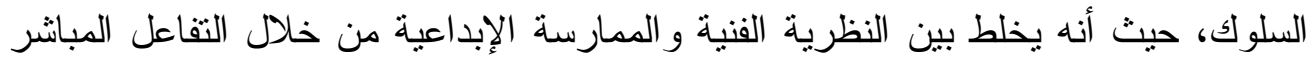

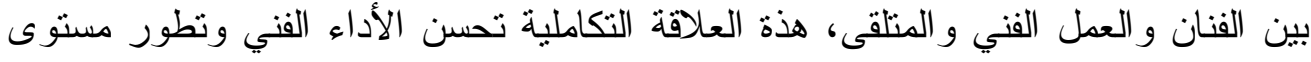

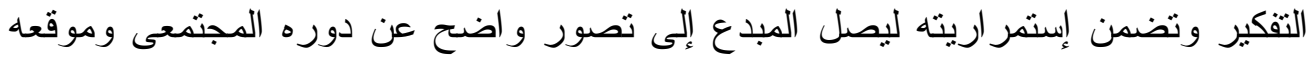


و إمكانيه تأثثره وحساسيته لما يحدث فى مجتمعه داخليا وخارجيا وبدون هذا الفهم لدور

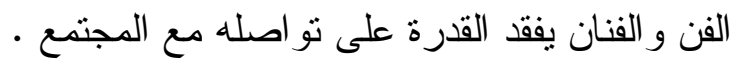

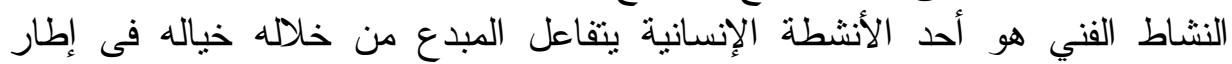

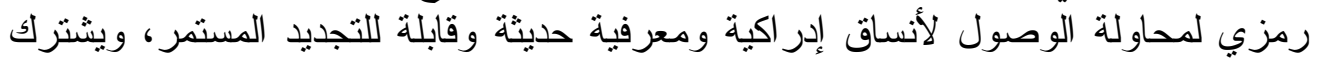

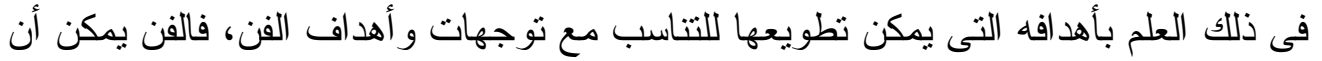

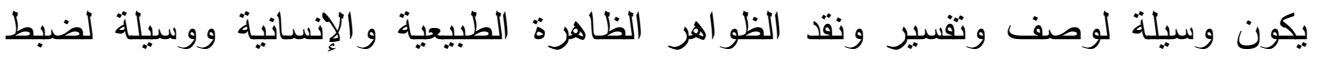

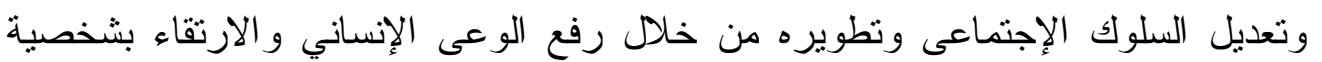

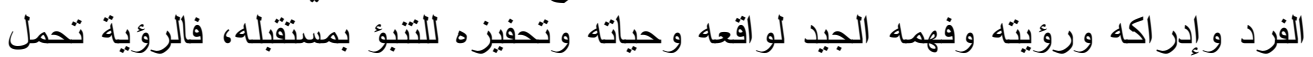

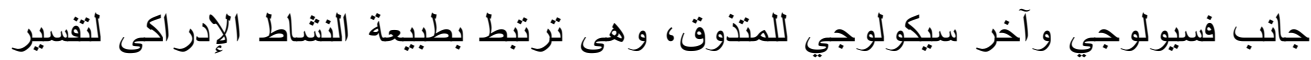

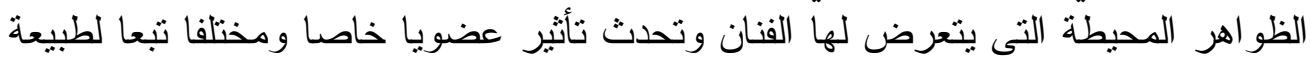

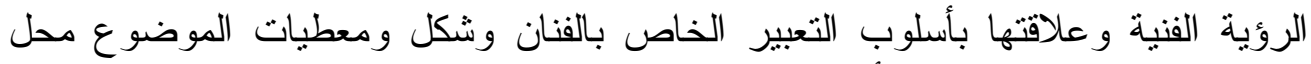

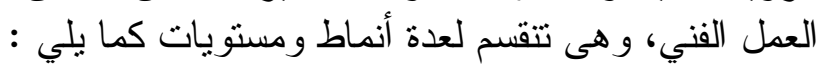

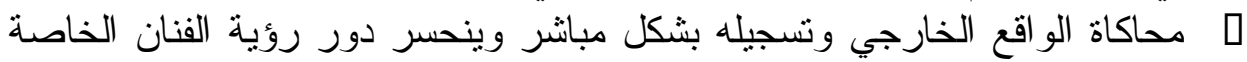
[ يظهر دور ورؤية الفنان فى تقويم التوجه الإبداعى و إطلاق دور الإدر الك فى الكى

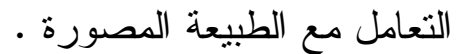
ييرز دور الفنان وسيطرة رؤيته وخياله ويتجاوز حدود الطبيعة لينتج تصورات

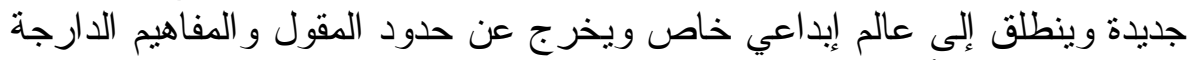

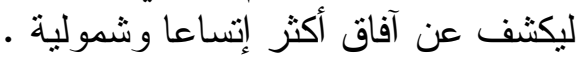

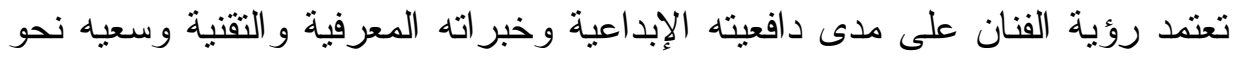

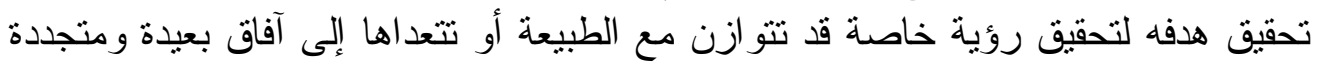

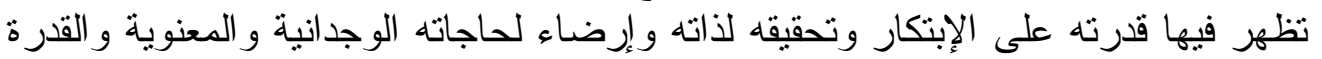

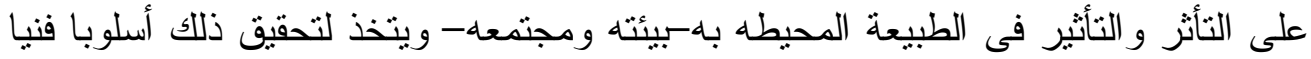

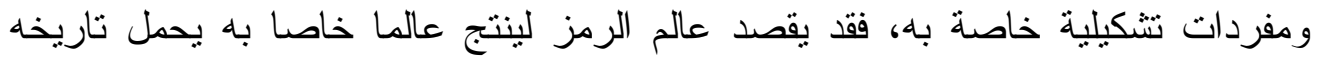

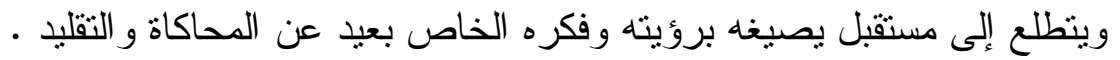

الشكل و المضمون

تبرز قضية الثكل وعلاقته بالمضمون كأحد إثكاليات عملية التفكير الإبداعى لفن

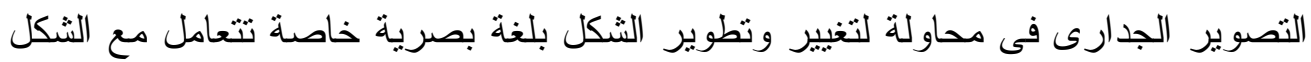

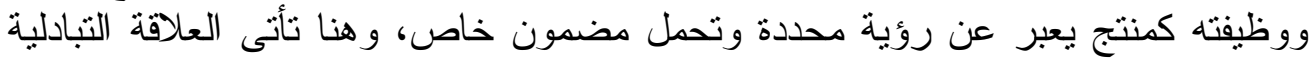

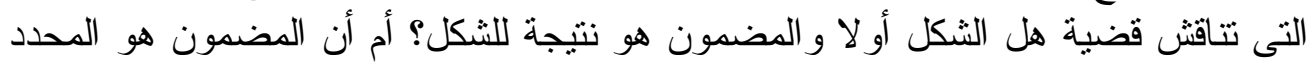

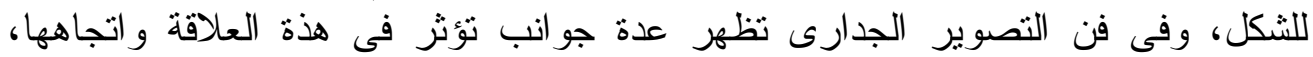

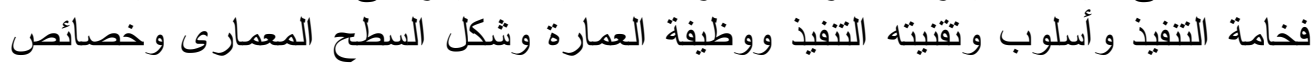

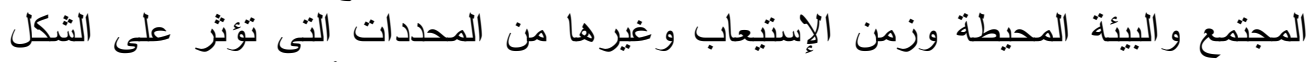

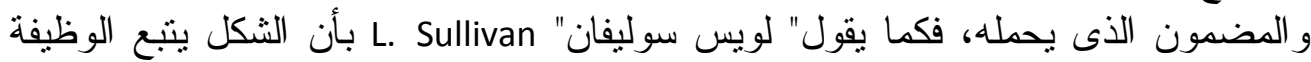
ويستمد وجوده وخصائصده من خلال طبيعة الموقع، فالثكل دون وظيل وليفة لاقيمة له، فالثكل 
ومفرداته من لون وضوء وخط و مساحة و غير ها وظيفتها إنتاج موضو عات وضات و أعمال إبداعية

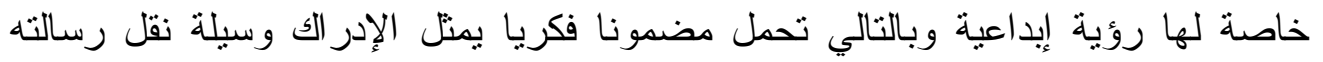

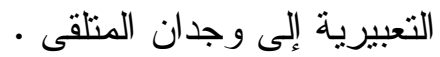

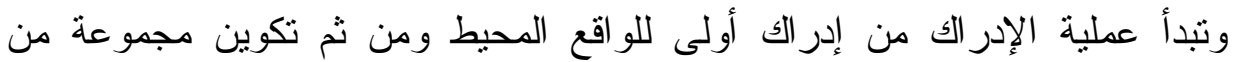

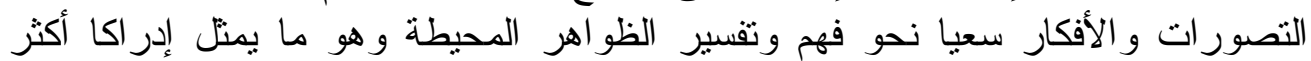

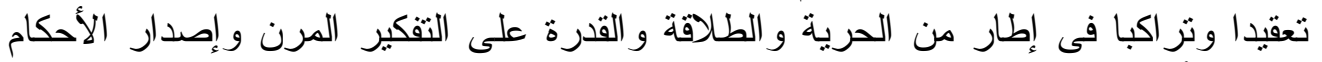

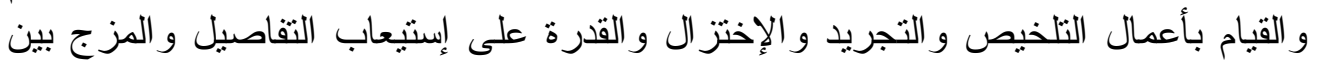

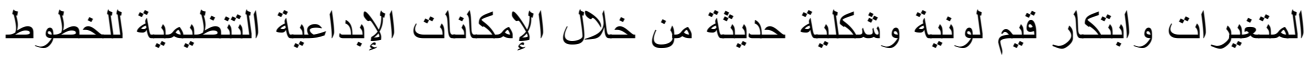

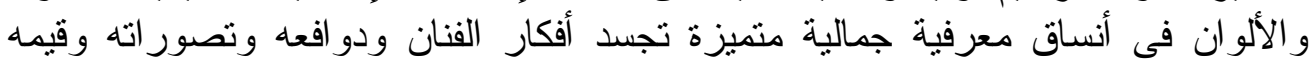

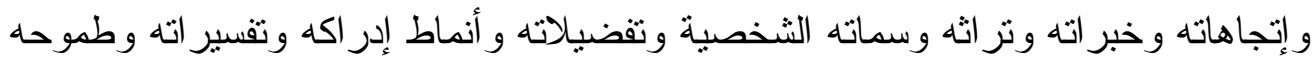

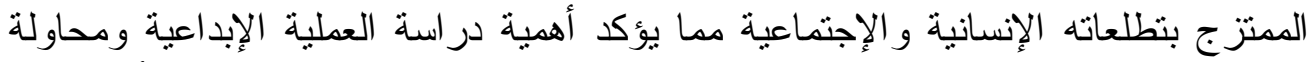

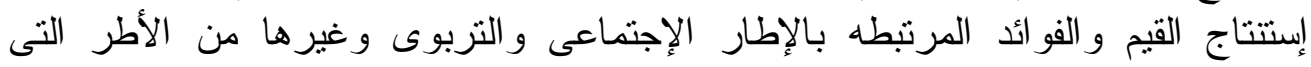

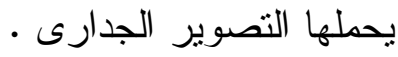

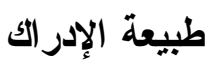

إن فن التصوير الجدارى لايخدم توجها مباشر ا بعينه، ولكن ذللك لا يعني أنه بلا هدف

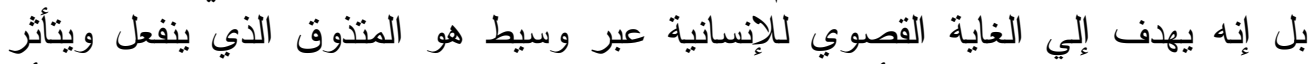

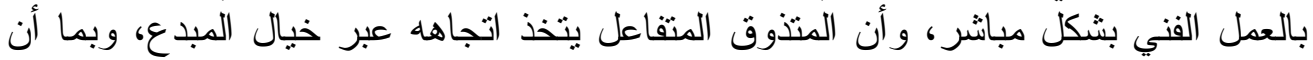

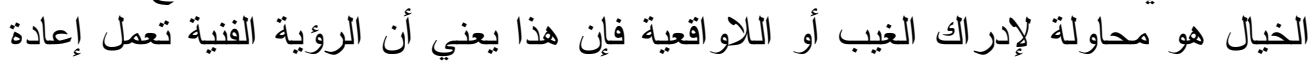

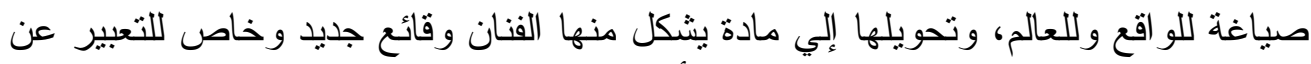

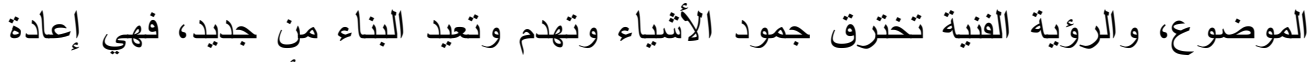

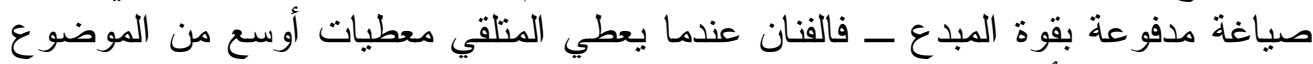

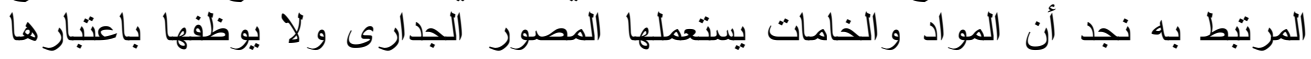

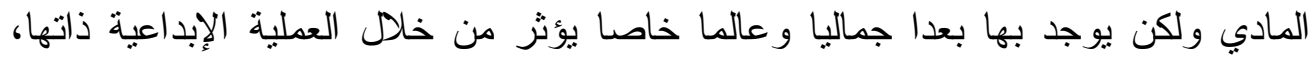

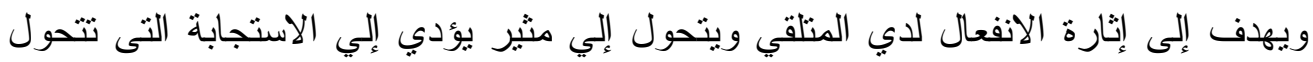

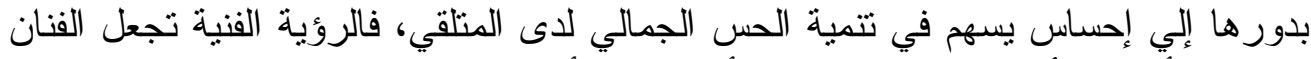

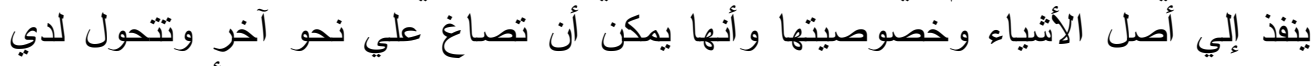

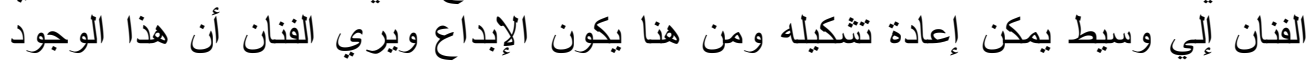

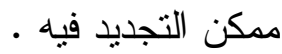

القيم الإبداعية و القيم الجمالية لفن التصوير الجدارى

- قيمة الجمال

الجمال كفكره ومفهوم غير ثابت يتغيـر حسب الزئ الزمان و المكان و البيئة و الثقافة،

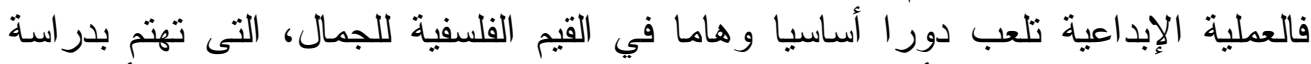

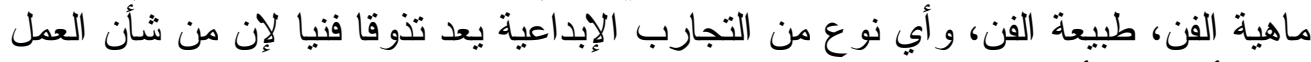

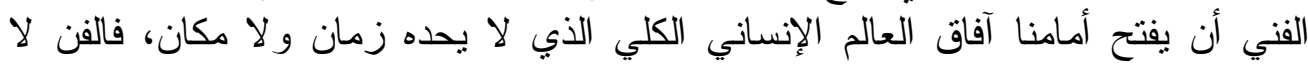




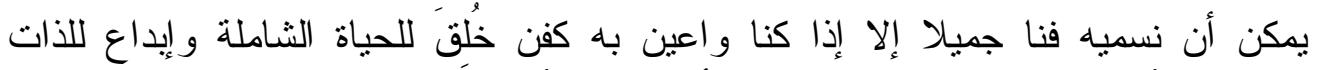

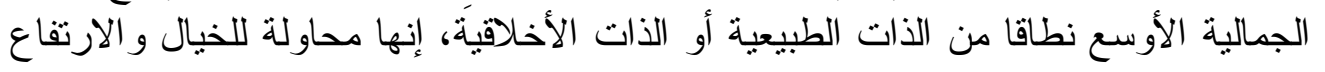

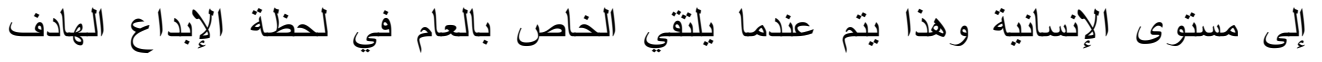

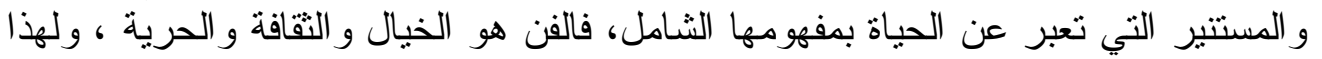

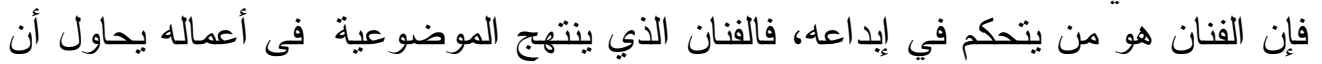

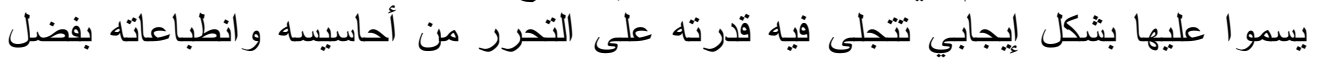

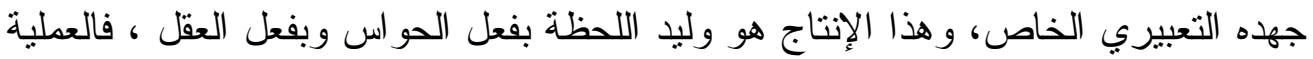

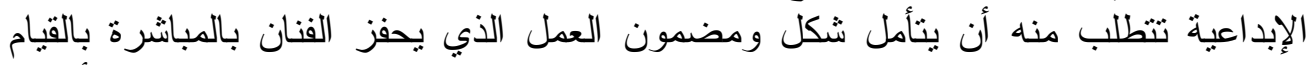

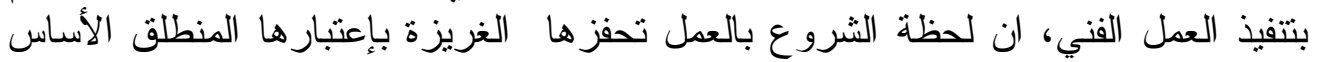

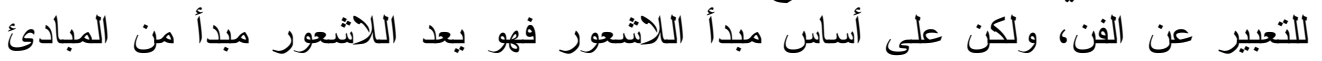

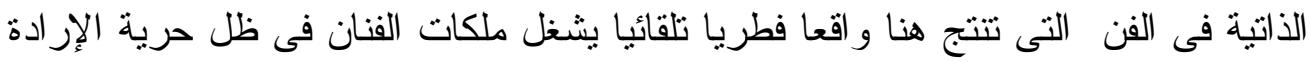

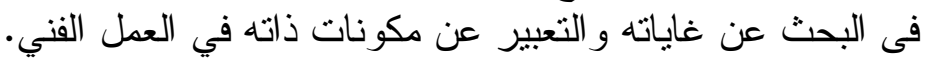

- قيمة الخيال

إن فان الفنان حينما يمارس عمله في الإنتاج الفني إنما هو يمارس قدر المن الخيال الخيال

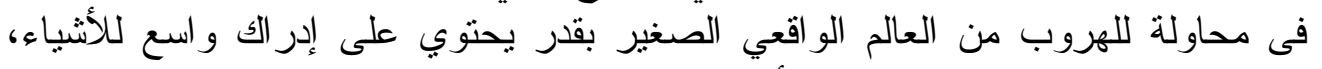

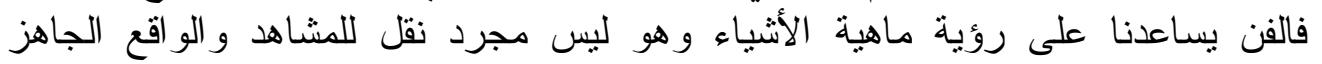

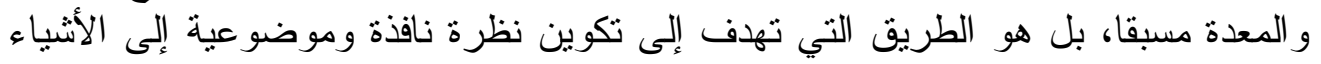

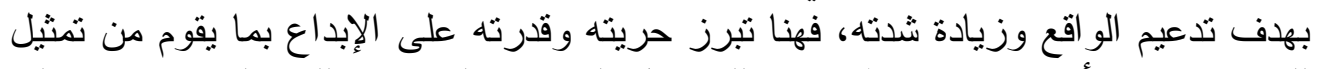

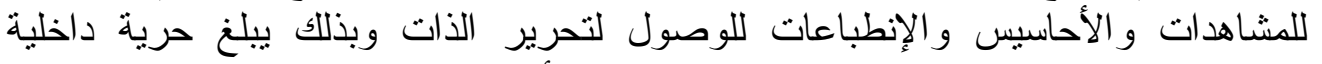

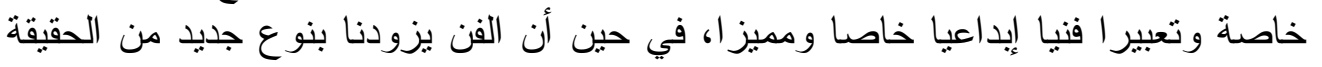

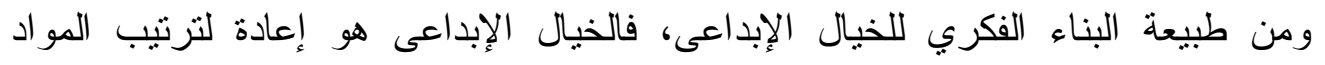
و وعناصر التكوين وتوزيعها بإعمال ملكات العقل و الحواس، لإل لكون الفن عملية بنائية تحتاج إلى هذين العاملين •

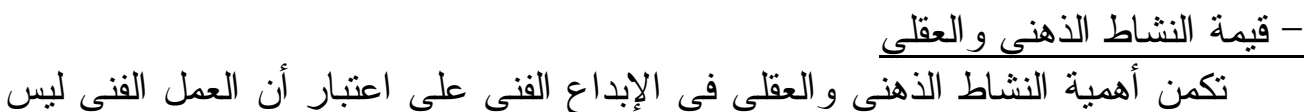

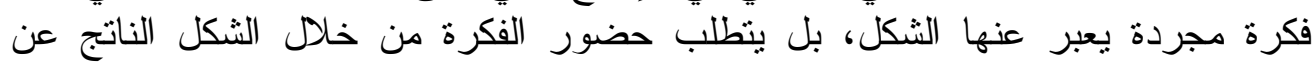

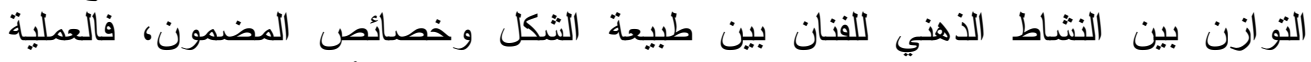

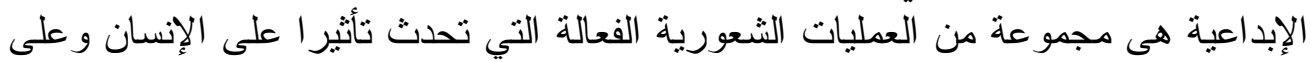

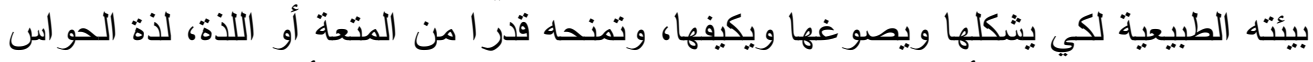

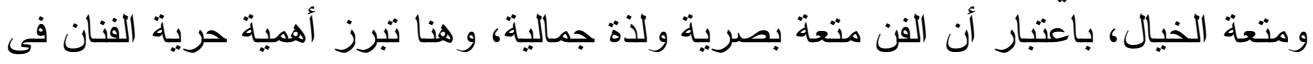

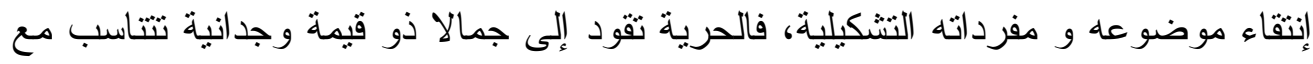

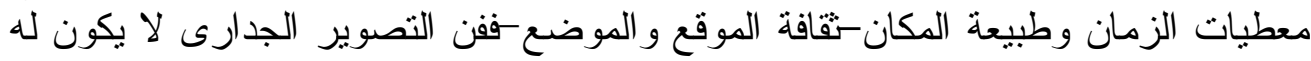

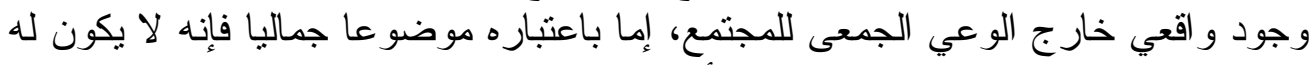

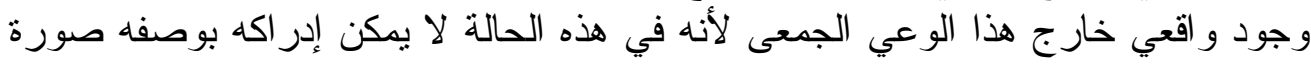

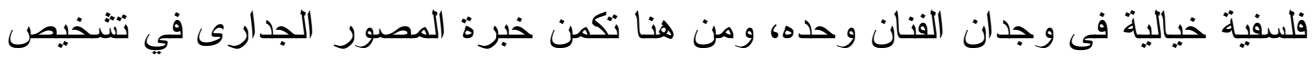


عمله شكلا و وضمونا بكونه بربط بين الثكل الفني والتجربة الإبداعية وخصائص البيئة

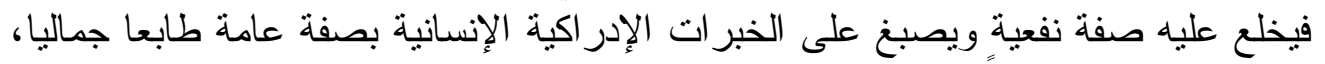

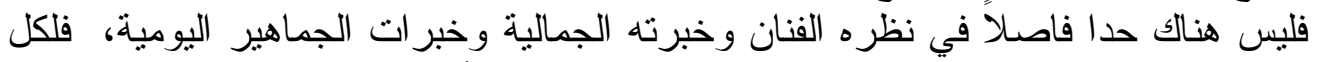

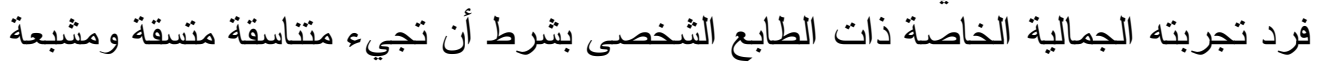

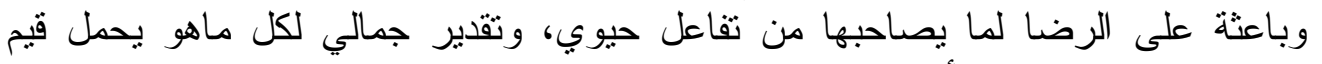

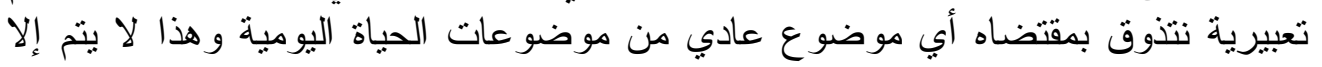

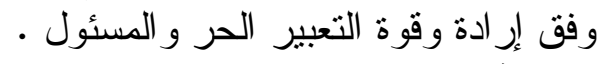

- قيمة الفكرة ادة وقة

إن عملية الإبداع الفني تتم تلقئيا دون وعى أو قدرة للفنان على التحكم فى إنفعالاته

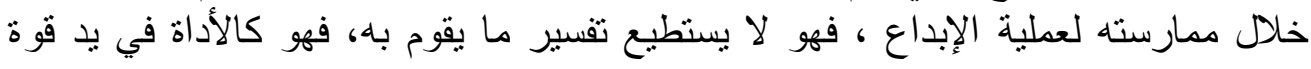

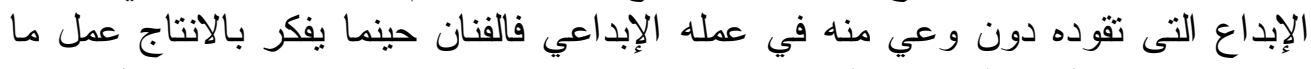

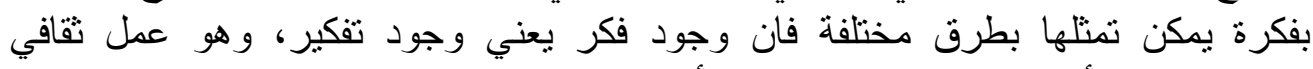

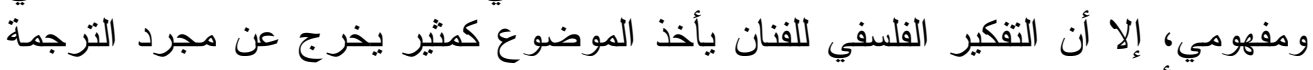

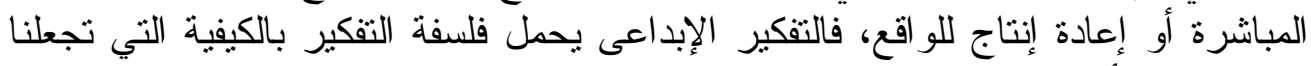

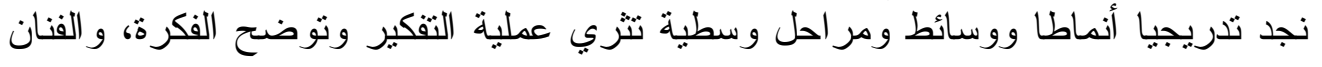

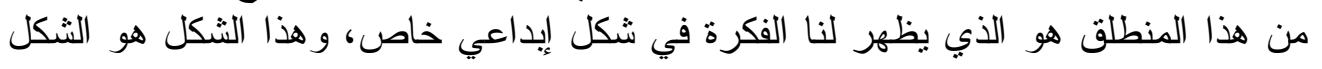

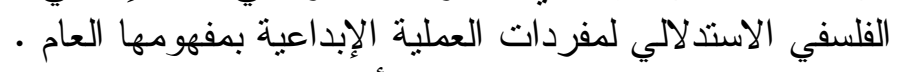

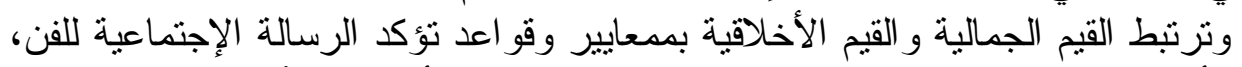

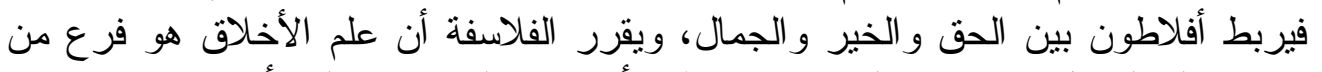

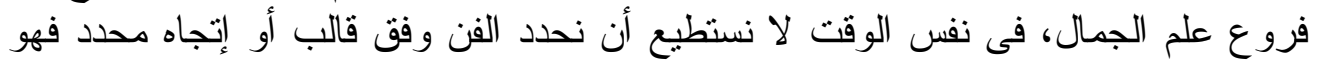

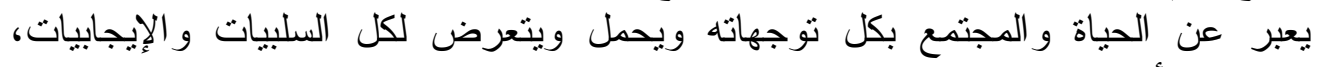

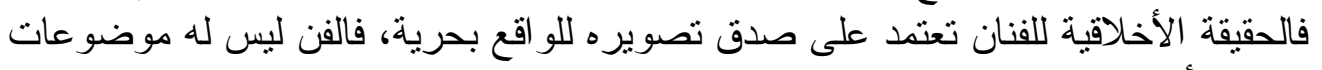

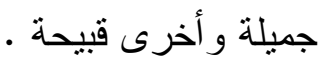

يقول" فلوبير" (أن الفشل يصيب جميع فنون الدعاية ذلك لأن القيمة الأيدولوجية لا يمكن أن

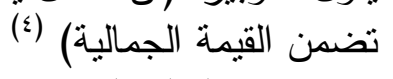

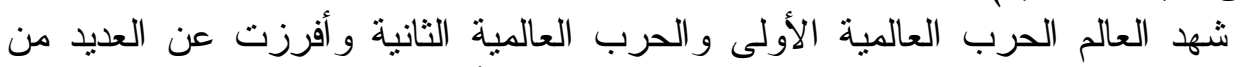

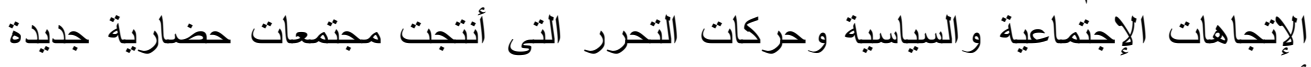

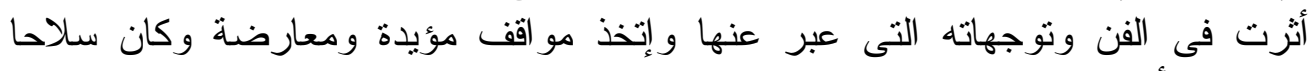

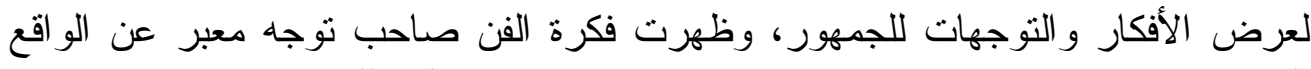

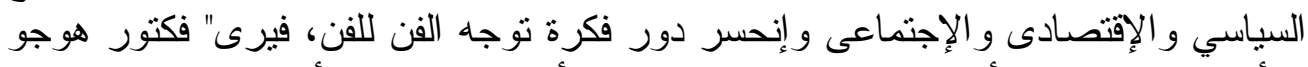

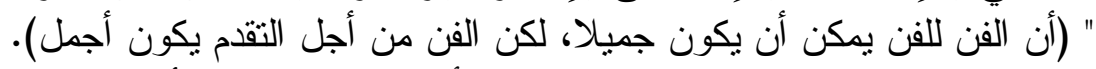

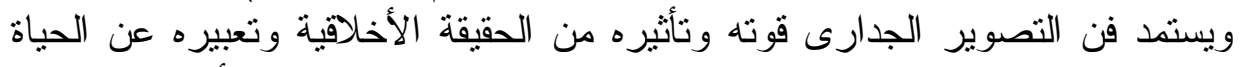

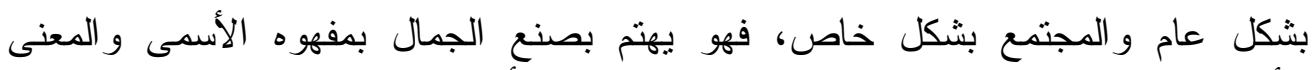

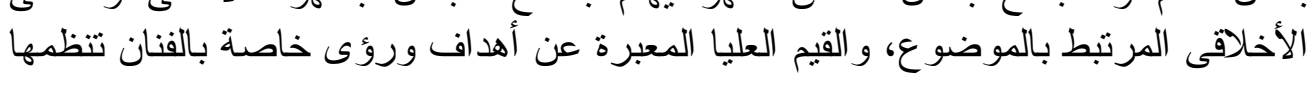


ضمير الفنان ويعمل فى إطار أخلاقي وإجتماعى ويخرج عن الإتجاه الاعائي الذى لا يحمل

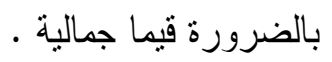

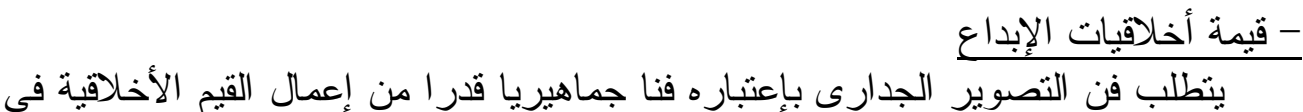

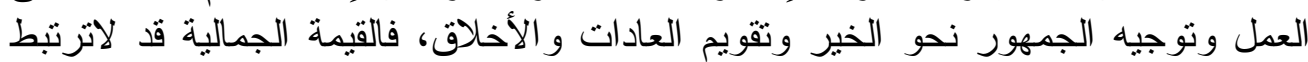

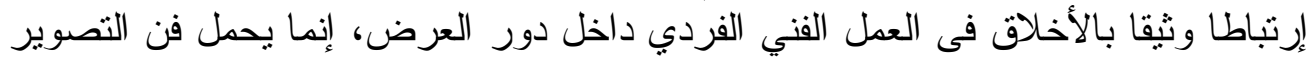

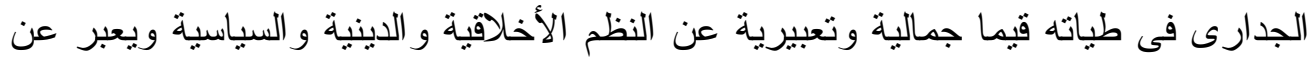

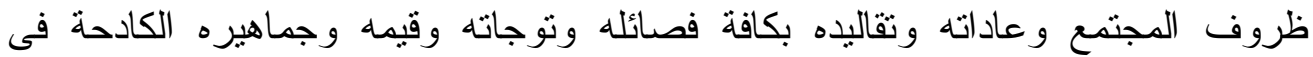

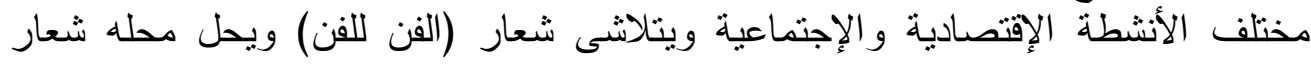

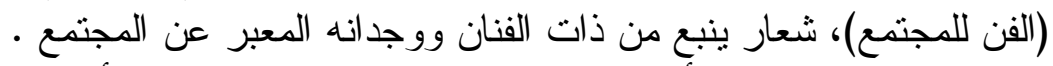

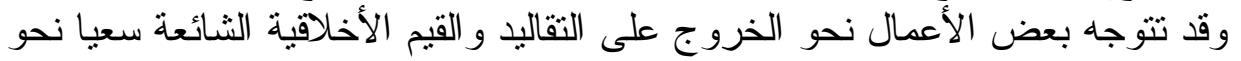

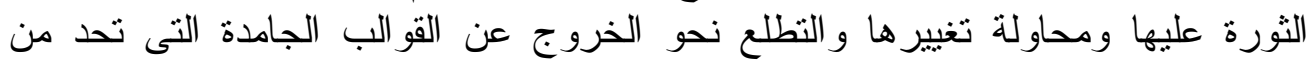

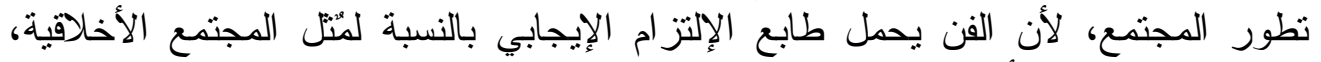

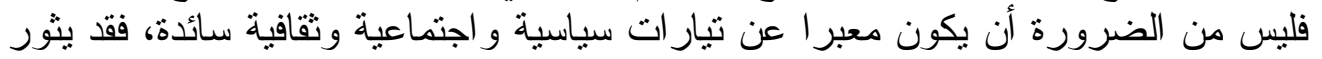

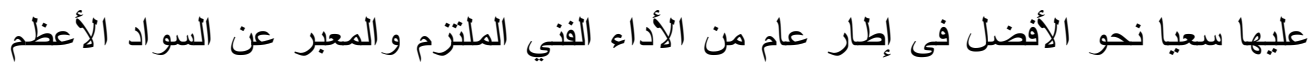

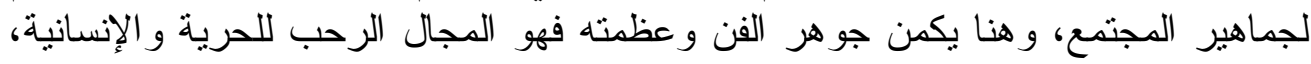

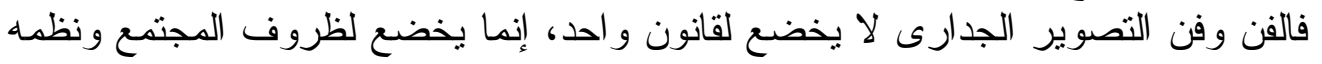

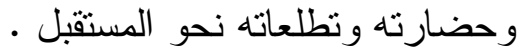

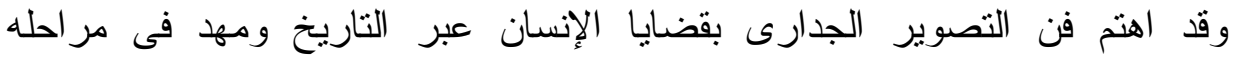

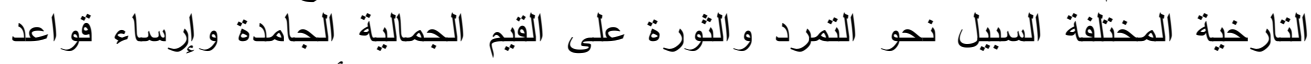

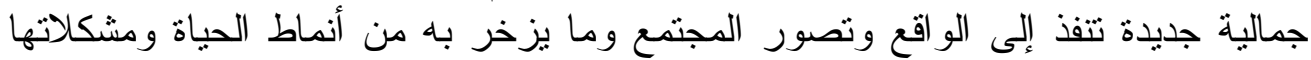

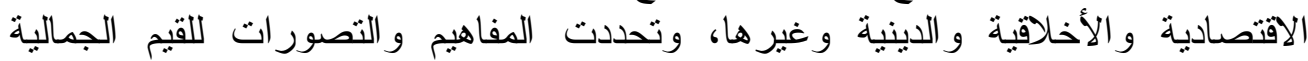

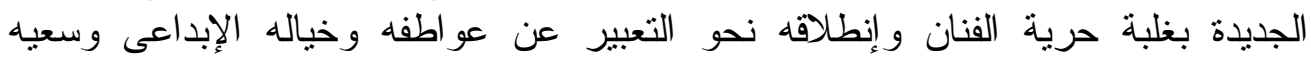

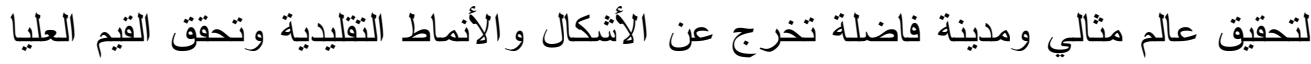

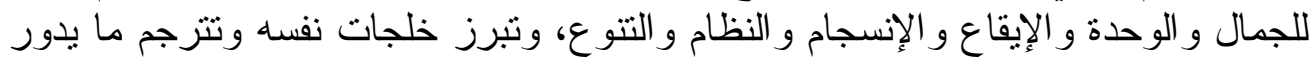

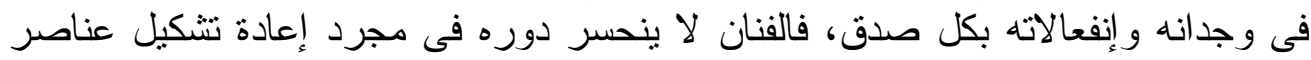

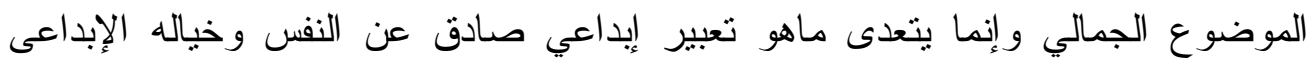

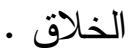

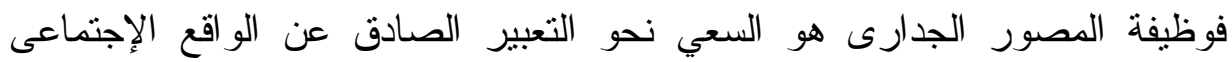

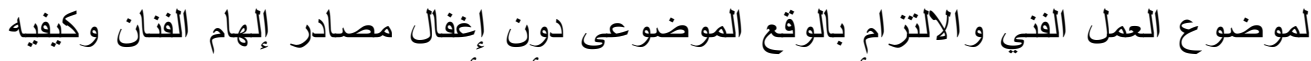

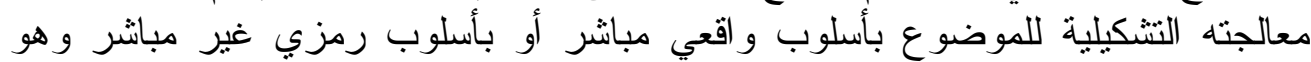

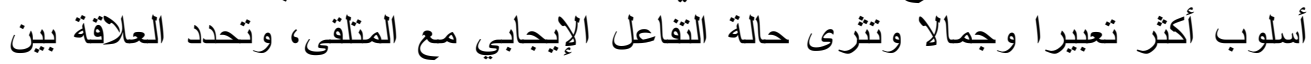

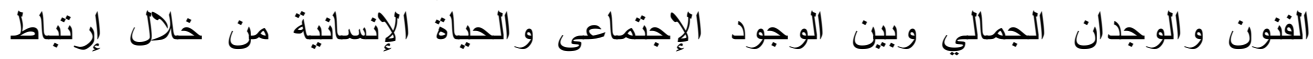

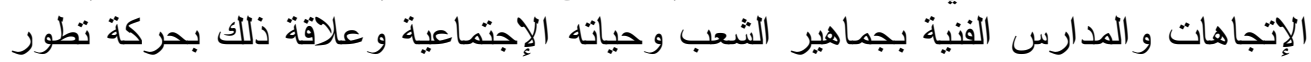


الثقافة والفنون والإبداع الفني وتعبيره عن الثكل و المضمون والطر از فى إطار زمني معاصر م

وتتطلق قيمة الجمال من القدرة على التعبير عن الموضوع و البيئة المحيطة، فقد شهد

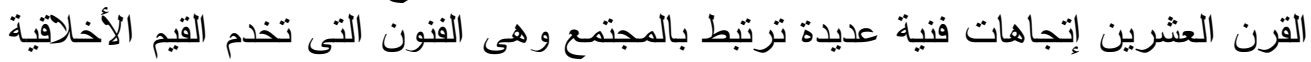

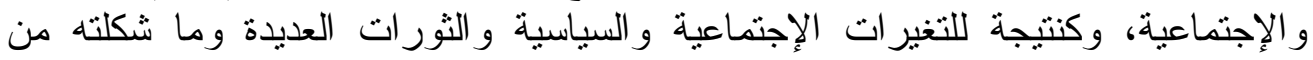

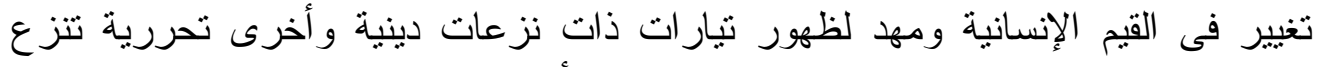

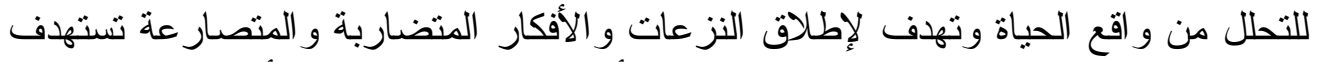

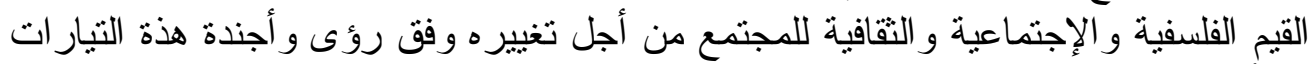

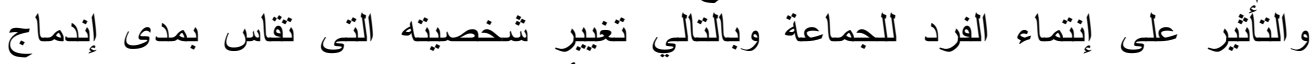

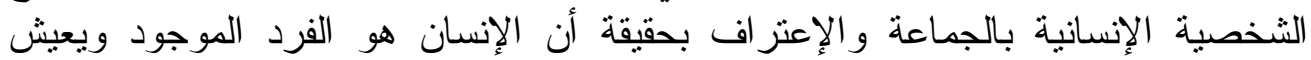

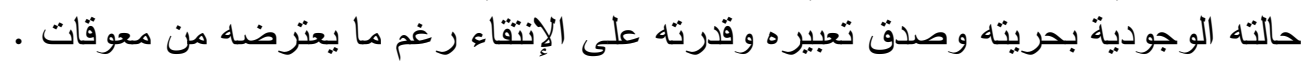

الخاتمة

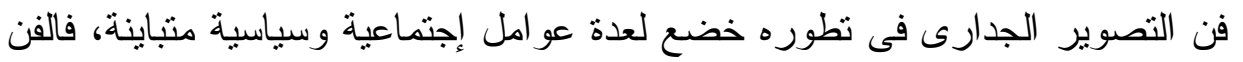

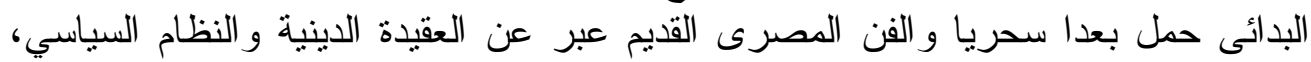

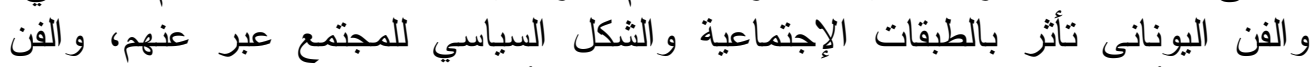

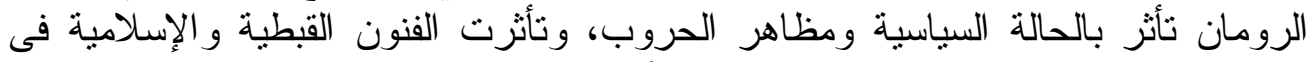

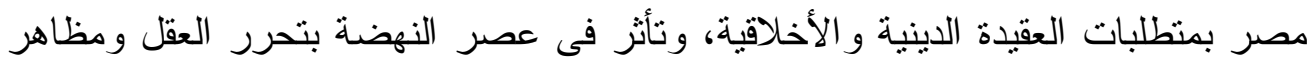

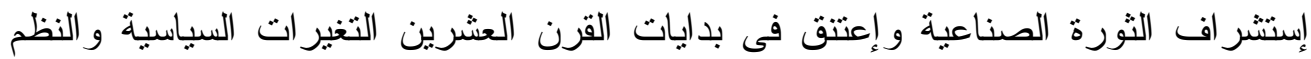
الإقتصادية و الإجتماعية المستحدثة .

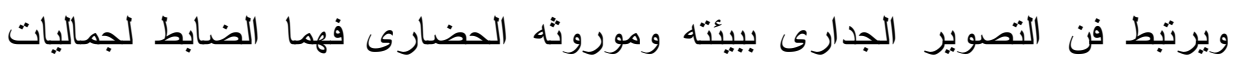

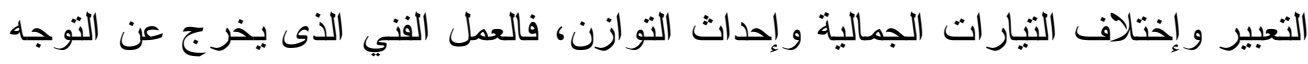

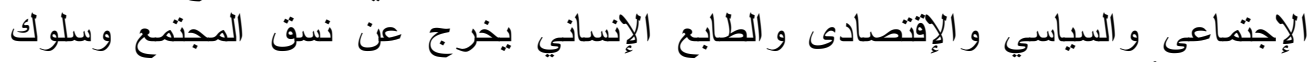

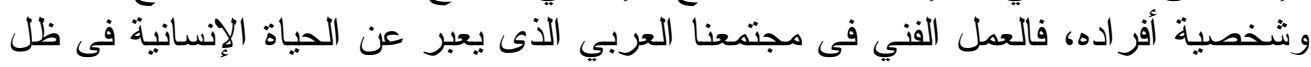

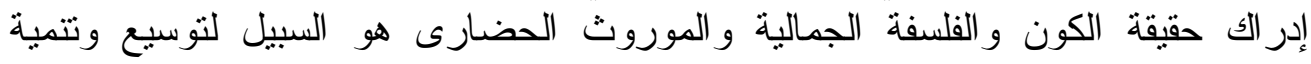

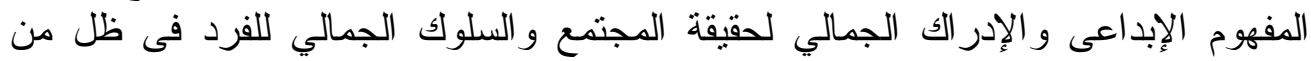

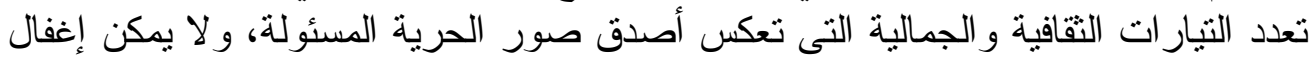

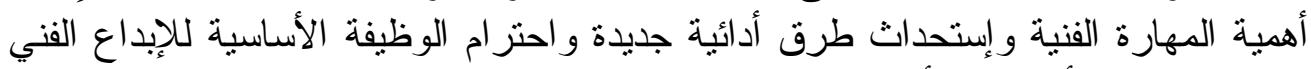

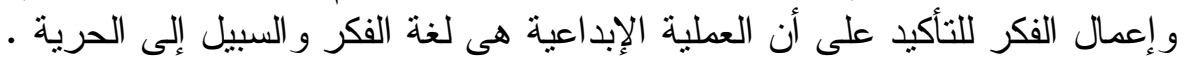




\section{نتائج البحث}

[ التجربة الفنية التى لم تتضج وسط بيئتنا وتحمل نبض الجماهير و وعق مشاعرهم

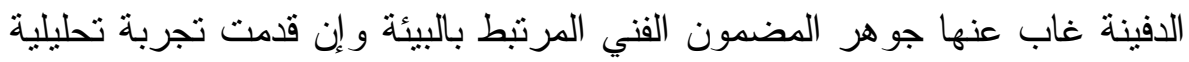
وتشكيلية خاصة .

] مائماً ما يحدث خلط بين مفهوم الجمال و الفن، فالجمال يرتبط بالوجدان بينما الفن هو إنتاج وإيتكار شيء مادي محسوس وفن التصوير الجدارى بإعتباره نشاطا

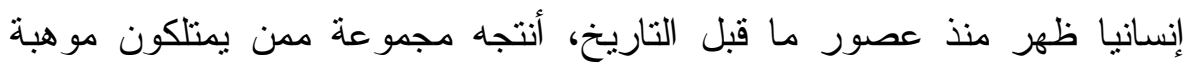
إبداعية و إيتكارية لديهم القدرة على التعبير عن طريق التئ الوسائط الفنية عن أفكار

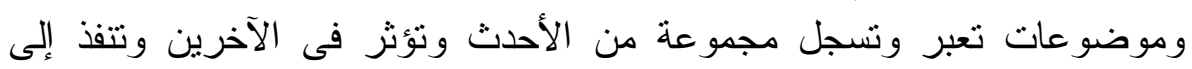

$$
\text { وجدانهم • مونو عات }
$$

C المصور الجدارى لا ينفذ عمله دون أن يتأثر ويتفاعل مع حدث أو موضوع معين

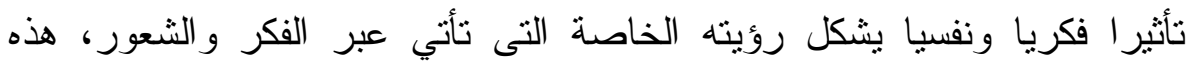

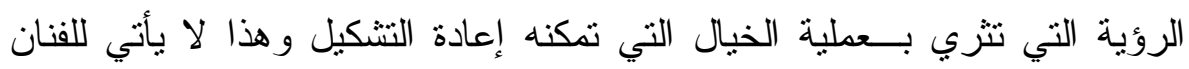
دون الخبرة المكتسبة من خلال التفاعل و التجربة .

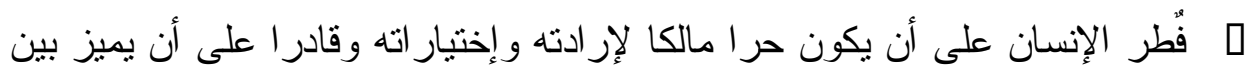

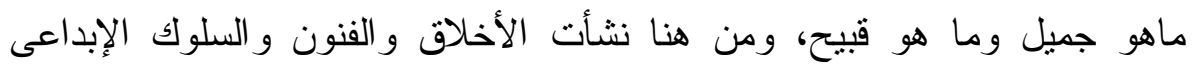

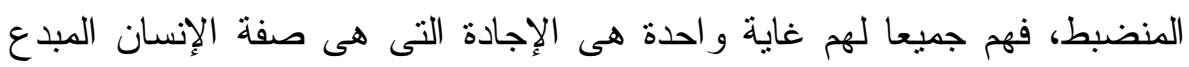

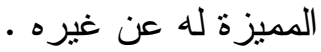
[ العملية الإبداعية المتميزة هى تعبير عن موهبة الفنان وجهده وخروجه للمتلقي حين بدأ حوار بين المتلقى و القيم الجمالية التى يثير ها العمل الفيرة الفني فى وجدانه وهن وهنا

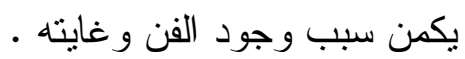




\section{مراجع البحث \\ ا المر اجع العربية}

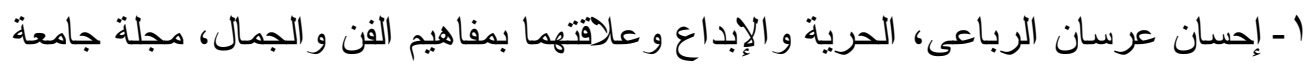

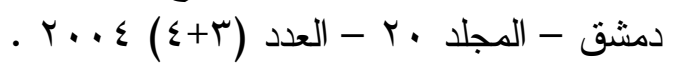

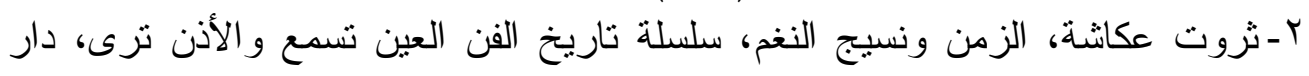

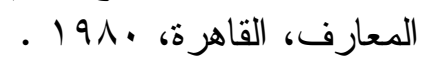

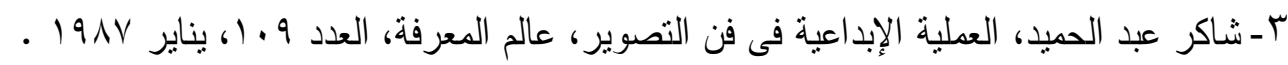

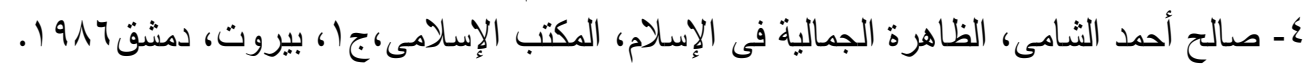

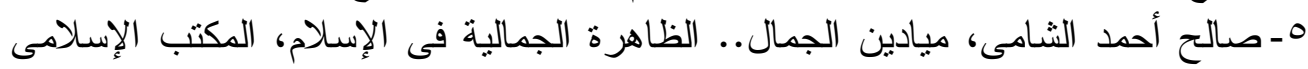

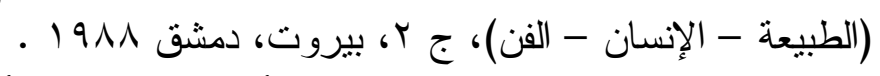

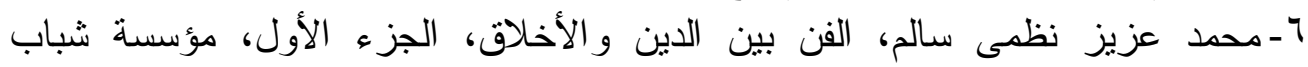

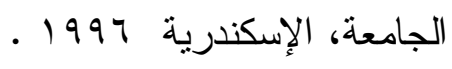

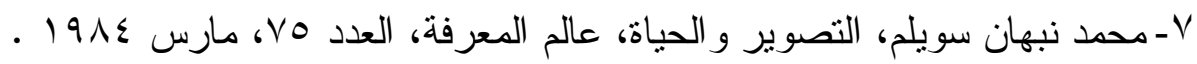

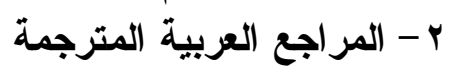

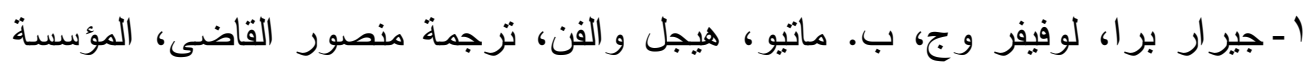

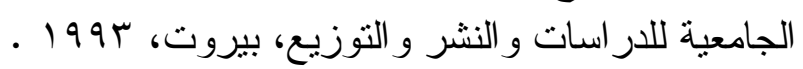

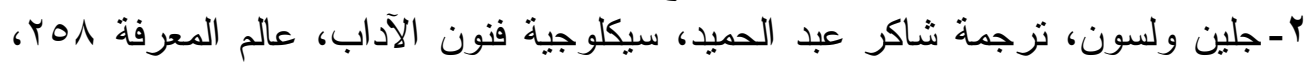

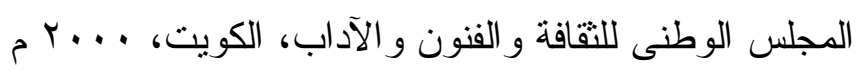

$$
\text { المراجع الأجنبية }
$$

- E. Kennick, Art and Philosophy ( Readins in aesthetics Sec.ed ) N.Y. 1979 .

- Wassily Kandinsky . Punto Linea Superfice . Adelphi Edizioni. 1968.

* ناقد فني ومفكر إنجليزى إجتماعى بارز عاش خلال القرن التاسع عشر وله العديد من

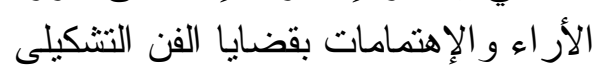
* محرر صحفى و ناقد فنى بمجلة علم الجمال و النقد الفنى لإنى 